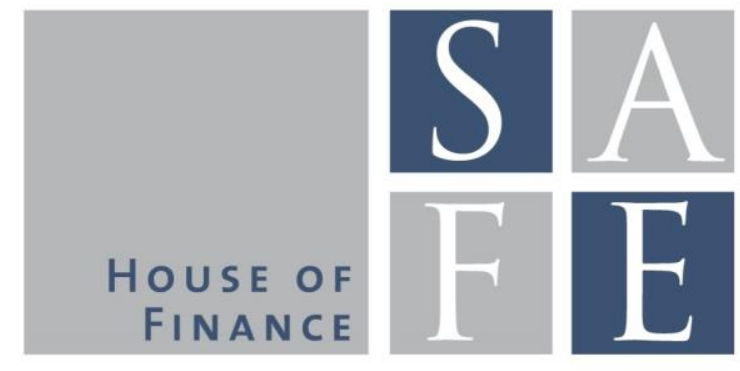

WORKING PAPER SERIES

Tobin Hanspal

\title{
The Effect of Personal Financing Disruptions on Entrepreneurship
}

SAFE Working Paper No. 161

SAFE I Sustainable Architecture for Finance in Europe A cooperation of the Center for Financial Studies and Goethe University Frankfurt 


\section{Non-Technical Summary}

Anecdotal evidence suggests that small business owners and entrepreneurs rely on personal loans, credit cards, and savings when starting or growing their businesses. A natural hypothesis is that if small business owners are exposed to personal financial losses or borrowing constraints, it may potentially affect the growth and survival of their firm. The academic literature has shown that financial crises and bank-specific credit supply shocks can have a large negative impact on commercial lending to firms. To date however, there is relatively little known about how firms respond to financing shocks experienced directly by entrepreneurs themselves.

In this paper, I attempt to fill this gap by asking how growth and survival of small firms are affected when an entrepreneur is directly exposed to personal financing disruptions. This focus may have been previously understudied because detailed information about the financial wellbeing of individual owners within a private firm is generally withheld from financial reporting. Furthermore, sources of personal financing are often correlated with characteristics of owners and potential determinants of firm performance, and a causal relationship is therefore difficult to identify.

To overcome these challenges, I use administrative data on firm owners which include detailed information on their personal assets and their retail banking relationships, merged to a comprehensive dataset on labor market activity. I identify bank-specific shocks by using variation in the solvency of retail banking institutions in Denmark following the 2007-2009 financial crisis. This period was characterized by extensive banking consolidation and bankruptcies of several retail banks which were publically traded on the Copenhagen Stock Exchange. These bankruptcies exposed small business owners who were retail bank investors to significant losses in personal wealth. Furthermore, for small business owners with savings and deposit accounts at affected banks, their ability to access to personal lending products deteriorated.

My results suggest that financial disruptions experienced individually by business owners have significant effects on firm survival and performance. I find that exposed firm owners are more likely to move their deposit account to a new retail banking institution following the default of their primary bank. This is correlated with a large decrease in their level of personal borrowing, and as such, increases the probability of firm closure. Exposure to personal liquid wealth losses for the firm owner stemming from lost investments increases the rate of firm exit for entrepreneurs holding investment accounts by approximately 5 percentage points, an economically meaningful result given a baseline rate of exit of 16 percent. This effect is stronger for owners with early-stage ventures. I find that entrepreneurs are significantly more likely to enter into salaried labor after losing substantial wealth holdings suggesting that these disruptions can have lasting consequences on labor markets. Finally, conditional on remaining in business, firm owners reduce employment after being exposed to financial losses.

In total, this paper shows that financial shocks experienced directly by firm owners can influence important decisions for the firm. Particularly in times of economic crisis, personal wealth and personal borrowing play a key role in entrepreneurial decision making. 


\title{
The Effect of Personal Financing Disruptions on Entrepreneurship*
}

\author{
Tobin Hanspal
}

December, 2016

\begin{abstract}
I show that disruptions to personal sources of financing, aside from commercial lending supply shocks, impair the survival and growth of small businesses. Entrepreneurs holding deposit accounts at retail banking institutions that defaulted following the financial crisis reduce personal borrowing and are consequently more likely to exit their firm. Exposure to the corresponding investment losses from delisted publicly traded bank stocks strongly reduces the rate of firm survival, particularly for early-stage ventures. At the intensive margin, owners who remain in business reduce employees after personal wealth losses. My results suggest that personal finance is an important component of firm financing.
\end{abstract}

JEL Classification: L26, D14, G01, G11, G21, G33

Keywords: Entrepreneurship; Small business; Personal finance; Financial crisis; Bank defaults

*Tobin Hanspal: Research Center SAFE, House of Finance, Goethe University Frankfurt, Theodor-W.Adorno-Platz 3, 60323 Frankfurt am Main, Germany. E-mail: hanspal@safe.uni-frankfurt.de. I thank Steffen Andersen, Claes Bäckman, Tobias Berg, Johannes Bersch, Thomas Fackler, Egle Karmaziene, Morten Sørensen, Mirjam van Praag, and seminar participants at the $3^{\text {rd }}$ CEPR European Workshop on Entrepreneurship Economics, Copenhagen Business School, the Danish Centre of Entrepreneurship Research, the EEA-ESEM Geneva 2016, the Evidence-Based Economics Summer Meeting 2016, Goethe University Frankfurt, and the ZEW $3^{\text {rd }}$ International Conference on the Dynamics of Entrepreneurship for helpful comments and suggestions. 


\section{Introduction}

How access to finance affects the growth and survival of firms is a fundamental question of entrepreneurial finance. Although there is ample evidence suggesting that credit market disruptions affect commercial lending and the borrowing ability of firms, we know relatively little about how firms respond to financing shocks experienced directly by entrepreneurs themselves. If small businesses are reliant on financing supplied by principal owner equity through savings, and debt financing from individual loans and credit cards, personal financing disruptions are likely to play an important role in the creation and dissolution of new businesses.

Previous literature has focused on how shocks to lenders are transmitted to firms and affect real economic activity. Researchers have studied this by using variation in bankbranch consolidation and measuring aggregate local market outcomes, ${ }^{1}$ with bank-firm matched data and detailed information on commercial lending, ${ }^{2}$ and by examining larger firms with access to syndicated loan and capital markets. ${ }^{3}$ By construction, the literature on credit market shocks largely excludes disruptions in personal finance in the outcomes of small business owners and entrepreneurial firms. Given the relative importance of small and medium-sized firms in the economy, it seems natural to ask how disruptions to retail banking and personal wealth affect the prospects of these enterprises. ${ }^{4}$ This channel may have been previously understudied for a number of reasons. Detailed information about the financial well-being of individual owners within a private firm is generally withheld from financial reporting. Datasets that link these firm owners to their personal financial market histories and experiences with information about the performance of their private firms are difficult to obtain. Finally, sources of personal financing are often correlated with characteristics of owners and potential determinants of firm performance, and a causal relationship is therefore difficult to identify.

In this paper, I take a first step in investigating how firms respond to idiosyncratic financing shocks experienced directly by small business owners. I use administrative data on firm owners which include detailed information on their personal assets and their retail banking relationships, merged to a comprehensive dataset on labor market activity. I identify bank-specific shocks by using variation in the solvency of retail banking institutions in Denmark following the 2007-2009 financial crisis. This period was characterized by extensive banking consolidation and bankruptcies, exposing entrepreneurs and small

\footnotetext{
${ }^{1}$ Berger and Udell (1998); Peek and Rosengren (2000); Ashcraft (2003); Greenstone et al. (2014); Nguyen (2014); Black and Strahan (2002); Adelino et al. (2014)

${ }^{2}$ Gan (2007); Khwaja and Mian (2008); Paravisini (2008); Degryse et al. (2011); Schnabl (2012); Iyer et al. (2014)

${ }^{3}$ Chodorow-Reich (2014)

${ }^{4}$ Small and medium-sized enterprises constitute for more than half of private sector employment in the OECD area, and more than 90 percent of firms employ less than 10 workers (OECD (2009)).
} 
business owners to differential, potentially exogenous personal financing disruptions. In the years preceding the financial crisis, Danish banking institutions increased their exposure to international capital markets and money markets in response to deposit deficits. As the financial crisis unfolded, many banks were cut of from this source of liquidity, and several financial institutions found themselves on the verge of bankruptcy. As a result of write-offs on domestic real estate investments, thirteen retail banks defaulted between 2008 and 2012, eight of which were publicly traded on the Copenhagen Stock Exchange. These banks were taken over by a state-owned financial supervisory authority. An additional twelve troubled banks resolved their liquidity needs in private merger and acquisition activity.

I build samples of entrepreneurs consisting of either deposit customers of retail banks or investors holding retail banking stocks in their investment portfolios. The variation in the solvency of banks after the financial crisis within depositor and investor samples, allows me to estimate the effect of changes in access to personal debt financing and the effect of unexpected changes in personal liquid wealth, respectively, on the performance and survival of a small business owner's firm.

Small business owners who held insured savings and deposit accounts in exposed retail banks were likely unable to access additional credit in the short run following the bank's default. These depositors were in turn more likely to move their account to another retail bank. I document the significance of this unexpected shock on debt accumulation for small business owners: the average exposed entrepreneur decreased his level of personal borrowing by more than 70,600 DKK $(\$ 12,800$ USD) relative to comparable unexposed small business owners in the years following the default of his personal retail bank. ${ }^{5}$

To understand how changes in personal liquid wealth may affect entrepreneurial survival, I turn to a sample of small business owners who held retail bank stock investments outside of their own bank in the years leading up to the financial crisis. As an attempt to increase capital, many retail banks followed an expansionary policy consisting largely of selling stock to individual investors since the year 2000 (Danish Financial Supervisory Authority (2009)). These investments were relatively common among investors. Prior to the financial crisis, $60 \%$ of all Danish investors held an investment portfolio containing the stocks of a retail banking institution. As several retail banks filed for bankruptcy, their shareholders were exposed to sizable investment losses. Conditional on investment in the banking sector, portfolios of exposed and unexposed investors were highly similar in composition and risk, however exposed entrepreneurs lost liquid assets from investments equal to 343,800 DKK $(\$ 62,500$ USD) at the mean and held approximately $30 \%$ less liquid wealth in the years after the financial crisis.

${ }^{5} 1 \mathrm{USD}=5.5 \mathrm{DKK}$. 
My results suggest that changes in access to debt finance and liquidity losses experienced individually by business owners have economically significant effects on firm survival and performance. I find that exposed firm owners are more likely to move their deposit account to a new retail banking institution following the default of their primary bank. This is correlated with a large decrease in their level of personal borrowing, and as such, increases the probability of firm closure by approximately 2 percentage points.

Exposure to personal liquid wealth losses for the firm owner stemming from lost investments increases the rate of firm exit for entrepreneurs holding investment accounts by approximately 5 percentage points, an economically meaningful result given a baseline rate of exit of approximately 16 percent. This effect is accentuated for less experienced and more financially constrained entrepreneurs. For entrepreneurs who started a firm in the years prior to the financial crisis, a one-standard-deviation increase in the ratio of losses to pre-crisis liquidity increases the probability of firm exit by almost 7 percentage points, or a 41 percent increase. A complete loss of liquid wealth for a new small business owner translates into a near 40 percent chance of firm failure. Furthermore, I find that entrepreneurs are significantly more likely to enter into salaried labor after losing substantial liquid wealth holdings suggesting that these disruptions can have lasting consequences on labor markets.

Consistent with the conjecture that firm owners may attempt to reduce costs prior to firm closure, I find that personal wealth losses of entrepreneurs result in significant intensive margin decisions. Conditional on remaining in business, firm owners reduce employment by approximately 0.72 workers after being exposed to financial losses, a substantial decrease given the average firm in the sample consists of 4.8 employees.

Do these disruptions affect small business owners via a consumer credit supply channel or are local banking defaults correlated with a demand shock that may contribute to firm closure? To answer this question I match entrepreneurs exposed to retail bank defaults with unexposed entrepreneurs located within the same local parish - a smaller subdivision of Danish municipalities. This allows me to isolate the effect of credit supply by controlling for differences in demand, as each matched entrepreneur pair are subject to the same local market. I find results comparable with those from the main specifications suggesting that the effect of disruptions are driven by changes in credit supply. As an additional robustness exercise, I focus on a subsample of firm owners whose firms are located in municipalities outside of where their retail bank is located and obtain similar results.

These results expand upon the existing literature which question the importance of the credit supply channel by asking if financial institutions transmit bank-specific shocks to firms. Schnabl (2012) analyzes how credit availability effects business lending to bor- 
rowing firms in Peru using the 1998 Russian default as an exogenous shock to bank-tobank international lending liquidity. Similarly, Khwaja and Mian (2008) use cross-bank changes in liquidity stemming from nuclear tests in Pakistan to show that firm borrowing of corporate loans is heavily reliant on bank liquidity. Iyer et al. (2014) uses the unexpected freeze of European interbank market to investigate the change of commercial and industrial loans to non-financial public firms in Portugal. Finally, Paravisini (2008) shows that an increase in government funding to local banks in Argentina increases total borrower debt without decreasing bank profitability. In addition, many researchers have used bank mergers as credit supply shocks to state-, county-, and even census track-level local markets and have considered the aggregate effects on rates of entrepreneurship and lending outcomes (Berger and Udell (1998); Peek and Rosengren (2000); Ashcraft (2003); Greenstone et al. (2014); Nguyen (2014), and Black and Strahan (2002)). Results generally show that bank consolidation in local markets and less banking competition reduce aggregate lending outcomes and firm activity.

Related to personal financing, several prominent studies have shown that individuals' initial wealth is an important determinant of start-up activity (Evans and Jovanovic (1989); Gentry and Hubbard (2004); Blanchflower and Oswald (1998)) and on performance and survival (Holtz-Eakin et al. (1994); Hvide and Møen (2010); Andersen and Nielsen (2012); Nanda (2011)). These studies have questioned the presence of financing constraints, whether initial wealth allows individuals from the general population to form a business, and the conditional performance of the venture. Surprisingly, there seems to be little evidence of how changes in owners' ability to provide financing may have effects that propagate ongoing firm dynamics and alter the survival or performance of established firms. One notable exception is Holtz-Eakin et al. (1994) who find that a sizable inheritance is correlated with a marginally higher propensity for an existing sole-proprietor to remain in business. Additionally, the previous literature has focused almost exclusively on positive wealth shocks such as inheritances or gains in housing wealth while financial losses have yet to be studied.

Finally, my results are related to a literature on entrepreneurial performance. Studies on entrepreneurial performance and firm survival have focused on the initial start-up conditions of the firm and on inherent characteristics of the firm's owner. For example, human capital endowments and demographic characteristics (Cooper et al. (1994); Shane and Stuart (2002); Van Praag (2003)), and prior experience of the owner (Lafontaine and Shaw (2016); Bayus and Agarwal (2007)). Recent research has considered how macroeconomic events may affect firm performance, e.g., the Great Recession (Cowling et al. (2012); Cowling et al. (2015); Zarutskie and Yang (2015)), and entry conditions and the business cycle (Fairlie (2013); Moreira (2016)). A number of studies have considered 
the capital structure of the firm at the onset of creation and its effect on performance or survival. Firms that self-finance and take on external debt seem to have higher rates of survival (Reid (1991)), initial outside debt seems to be correlated with higher firm revenues later in the firm's lifecycle (Robb and Robinson (2012)), early start-up loans have a strong impact on survival (Fracassi et al. (2013)), and firms supported by lending programs fare better with higher rates of growth (Brown et al. (2015)).

I contribute to the existing literature above by showing that personal financing disruptions, aside from shocks which affect commercial and business lending, can have large effects on the survival and growth of entrepreneurial firms. My analysis looks specifically at firm outcomes and performance rather than intensive margin changes in borrowing and lending. In addition, I focus on smaller, entrepreneurial firms and small business owners in an advanced European country and use high quality, complete, administrative data from Denmark eliminating sources of measurement error.

The study proceeds as follows: In Section 2 I discuss the motivation and institutional background. The following section discusses in detail the sources of data and the sample. In Section 4, I discuss the identification strategy and empirical approach. Section 5 discusses the results and follows with additional specifications and robustness checks. The final section concludes.

\section{Background}

\subsection{Characteristics of Entrepreneurial Finance}

For most new firms the majority of capital financing comes from outside debt via personal loans made to the owner, commercial loans, and personal and business credit cards, as documented by Robb and Robinson (2012). The authors consider outside debt which is either a claim on the owner's personal assets or on the business's assets. Furthermore, their analysis suggests that personal debt is a significant component of early stage financing. More than 50 percent of the average firm's early financial capital stems from personal debt. On the extensive margin approximately 26 percent of firms use business lending and business credit cards, while 20 and 31 percent of entrepreneurs use personal bank loans and personal credit cards. ${ }^{6}$

The Kauffman Firm Survey data further suggests that more than $75 \%$ of firms are financed by at least some degree of owner equity (Robb and Robinson (2012)). Of these firms, owners provide on average $\$ 40,500$ of financing. Equity investments therefore make up a substantial fraction of household wealth for established small businesses, as pointed

\footnotetext{
${ }^{6}$ These values can be computed from Table 4 of Robb and Robinson (2012).
} 
out by Moskowitz and Vissing-Jorgensen (2002), households with entrepreneurial equity on average invest more than $70 \%$ of their wealth in their own business. Berger and Udell (1998) show that smaller enterprises (less than 20 employees) finance their firms with a larger share of principal owner equity compared to larger firms (45\% compared to $27 \%$ ), and owner equity increases with the age of the firm while commercial and personal bank debt decrease. ${ }^{7}$ Robb and Robinson (2012) find that for smaller businesses, owner equity constitutes approximately one-third of total financial capital in a firm's first year of business and a sizable fraction of initial and subsequent capital injections during operations.

If performance and survival of early stage firms is reliant on personal sources of financing, shocks that affect this channel should have a large detrimental effect on small businesses. Unexpected changes in the owner's balance sheet should affect the owner's ability to supply the firm with ongoing capital injections. Similarly, if growth or survival of a small firm is reliant on personal debt financing, external credit shocks affecting the owner's ability to obtain personal bank loans may affect the firm as well. In addition, it is possible that facing personal financing shocks, entrepreneurs may choose to withdraw equity or liquidate a venture in order to support existing commitments.

For small businesses, shocks that affect these personal financing channels (wealth and debt) are somewhat separable. Changes in personal wealth should have a limited effect on an owner's ability to secure lines of credit from his bank, as owners are most likely to pledge their housing assets as outside collateral for debt financing (Parker (2009)). Personal wealth changes however, have large implications on the ability to supply the firm with capital. Inversely, changes in access to bank lending and available credit should hamper an entrepreneurs ability to obtain debt financing to fund an existing venture without directly affecting his liquidity position.

\subsection{The Danish Retail Banking Sector}

In the years preceding the financial crisis, Danish banking institutions saw a fundamental shift in the way that they accessed financing to lend to their customer base. ${ }^{8}$ As a result of widespread deposit deficits, the retail banking sector turned to international capital and money markets in order to raise liquidity through new channels of financing. This in turn increased their exposure to international financial market fluctuations (Rangvid et al. (2013)). Prior to the financial crisis, however there was little concern that market

\footnotetext{
${ }^{7}$ See Table 1 in Berger and Udell (1998) for more information.

${ }^{8} \mathrm{~A}$ feature of the banking environment in Denmark is an abundance of smaller, publicly held retail banks. In addition to the five largest retail banks (Danske Bank, Nykredit, Nordea Bank, Sydbank, and Jyske Bank), many smaller, local, retail banks are also publicly held and traded on the Copenhagen Stock Exchange.
} 
financing may 'dry up.'

With the default of Lehman Brothers in the fall of 2008 Danish retail banks were effectively cut off from these international capital markets they had grown accustomed to. At the same time, many Danish banking institutions held sizable investments in domestic real estate and farmland, and as the financial crisis unfolded in the United States, asset values in these markets crumbled. This triggered a flight to liquidity, where some banks experienced the contraction more severely than others.

A group of small and medium-sized financial institutions were hit particularly hard. Indeed, there was considerable variation in how severely banks were affected (Rangvid et al. (2013)), and many banks were on the verge of defaulting on their obligations. Between 2008 and 2012, as a result of write-offs on real estate investments, thirteen retail banks defaulted, eight of which were publicly held. These thirteen default banks were taken over by the financial supervisory authority, while an additional twelve troubled banks consolidated with existing banks in private arrangements. ${ }^{9}$ The municipalities where the troubled banks were headquartered were distributed throughout Denmark, as shown in Figure A.1.

\section{Data}

I access administrative register data encompassing the universe of all legal Danish residents and assemble a dataset of individuals spanning 2002 to 2012. My dataset contains economic, financial, and personal information about all individuals. The dataset is constructed based on several different administrative registers made available from Statistics Denmark.

Individual-level data originate from the official Danish Civil Registration System. These data provide individual characteristics, such as age, gender, and marital status, and give unique identification across individuals and time. Educational records are from the Danish Ministry of Education. All completed (formal and informal) education levels are registered annually and made available through Statistics Denmark. Income, wealth, and employment status are from the official records at the Danish Tax and Customs Administration (SKAT). This dataset contains personal income and wealth information by individual social security number (CPR) for the Danish population. SKAT receives this information directly from the relevant sources; financial institutions supply information to SKAT on their customers' deposits and holdings of investments. Employers similarly supply statements of wages paid to their employees.

\footnotetext{
${ }^{9}$ Refer to Appendix A.1 for additional information.
} 
From SKAT, I gain access to a database of NEM-ID accounts. This data contain the 4digit registration number of each individual's primary retail banking account at year-end, from 2005-2012. I map these registration numbers into retail banks across Denmark using a hand-collected database. In addition, I obtain access to ISIN-level stocks and mutual funds from 2006-2012 for all equity market participating Danish individuals. This data provides year-end information on the specific composition and the value of individual investment portfolios held outside of pension accounts.

\subsection{Entrepreneurship Data}

The above datasets are complemented with a matched employer-employee panel dataset drawn from the Integrated Database for Labor Market Research in Denmark (IDA). In this register database, entrepreneurship and self-employment are defined by primcr arbejdsstilling, or primary occupation. For each individual, I observe the annual primary occupation as designated in the last week of November. The dataset allows me to identify entrepreneurs precisely, distinguishing between self-employment and part-time work. The administrative designation of employment removes measurement error typically contained in survey data. ${ }^{10}$ I define self-employed individuals as individuals who have a primary occupation code of individual tax payer or employer who employ no other individuals in the firm. Most importantly, entrepreneurs, are defined as individuals with a primary occupation of employer and employ at least one other individual in the firm, similar to the definition used in Jensen et al. (2014), Nanda (2008), Nanda and Sørensen (2010), and Nanda (2011), among others. By definition these individuals are owners of ventures with unlimited liability (UL), which encompass approximately 63 percent of new Danish enterprises (Statistics Denmark (2016)).

The data do not allow me to identify firm owners with limited liability (LL). This however, is not problematic for my analysis as LL entrepreneurs are employees within their company, rather than employers employing others (Nanda and Sørensen (2010)). Throughout the analysis I therefore compare exposed UL firm owners with unexposed UL firm owners, rather than a sample consisting of various types of firm owners. This somewhat reduces external validity, as I cannot characterize personal financing and owners of firms with limited liability. To that end, I use firm owners, small business owners, and entrepreneurs interchangeably but the sample is likely more representative of small owner-managed businesses rather than technology start-ups. Finally, because I use the IDA database on UL firm owners, I do not observe the business assets or revenues of the firm, only the individual assets of the firm owner him- or herself. ${ }^{11}$

\footnotetext{
${ }^{10}$ See Jensen et al. (2014) for a more in depth discussion of this dataset.

${ }^{11}$ A possible extension of this analysis would be to focus on LL firms where firm asset and revenue data is more
} 


\subsection{Sample}

To be included in the final dataset, individuals must have a full record for each year for inclusion, including a retail bank account. I then exclude any individuals with missing employment information during any year as well as individuals with incomplete education records. Finally, I limit the sample to individuals over the age of 25 and under the age of 60 in order to avoid entrepreneurs retiring from their businesses or withdrawing equity in pre-retirement years. This dataset results in 1,643,542 individuals in the year 2006, 30,082 (1.83 percent) of whom are entrepreneurs who employ other individuals. Appendix A.2 shows that these entrepreneurs have an average firm size of 4.8 employees.

Table 1 reports summary statistics for all individuals in the sample in the year 2006. The table divides individuals by their primary employment; Column 1 focuses on all individuals in the sample, Column 2 on self-employed individuals, Column 3 on entrepreneurs that employ at least one other individual, and Column 4 on individuals who are in traditionally salaried labor employment. Consistent with the existing literature, entrepreneurs are more likely to be male, married, and have more children than their salaried counterparts. Additionally, they have significantly higher income with a higher standard deviation, and have accumulated more net wealth - while holding significantly higher levels of debt in their mortgage and personal bank loans. In fact, entrepreneurs have approximately ten-fold the amount of personal bank debt as salaried employees. This highlights the relative importance of personal banking loans on the balance sheets of entrepreneurs. ${ }^{12}$

\section{Empirical Strategy}

If the performance of entrepreneurial firms is related to the firm owner's ability to obtain debt financing or available liquid wealth, the relationship can be summarized by the following,

$$
y_{i t}=\beta_{0}+\beta_{1} \Delta \text { credit }_{i t}+\beta_{2} \Delta \text { liquidity }_{i t}+\lambda X_{i t}+\epsilon_{i t}
$$

where $i$ indexes individual-entrepreneurs, $t$ indexes the calendar year, and $y_{i t}$ is the dependent variable measuring the performance of entrepreneur $i$ 's firm. The vector $X$ consists

\footnotetext{
widely available, however this is outside the scope of this current paper.

${ }^{12}$ Personal bank loans may include a top-up loan to facilitate initial mortgage down-payments. These are discussed in further detail in Jensen and Johannesen (2015), however they are not unique to entrepreneurs and are not what drives the differences between entrepreneurs and salaried individuals. In later analysis I show that personal bank loans are a key factor for individuals who own substantial traditional housing assets and are therefore unlikely to be affected by these products.
} 
of individual-entrepreneur financial and demographic characteristics. Estimating Equation 1 directly could lead to bias as access to credit and available liquidity measures may be correlated with unobservable characteristics captured in $\epsilon_{i t}$, which could influence the outcomes of their entrepreneurial firms. Moreover, firm performance could affect the level of liquid assets or credit an entrepreneur has access to. To test the role of personal disruptions to debt financing and personal liquidity on firm outcomes, the ideal experiment would randomly allocate established entrepreneurs into three groups; one where entrepreneurs are made constrained in their access to credit; one where liquid wealth is taken away from entrepreneurs; and finally one unaffected control group for comparison.

Although this experiment is likely infeasible, the Danish banking environment during the financial crisis proves to be a next-best research design. The heterogeneous exposure to changes in debt finance and personal liquidity allows me to estimate the causal effect on firm survival summarized by a multiple-treatment difference-in-differences specification, given by the following reduced-form equation:

$$
y_{i t}=\alpha_{t}+\rho_{i}+\gamma \text { exposed }{ }_{i t}^{j}+\beta X_{i t}+\epsilon_{i t},
$$

where $\alpha_{t}$ and $\rho_{i}$ are year and individual-entrepreneur fixed effects, respectively, which account for variation across the sample years and time-invariant differences between individuals. Exposed ${ }_{i t}^{j}$ proxies a change in either access to credit, or available liquid wealth, indicated by superscript $j$. For variation in access to credit across entrepreneurs, I define unexposed and exposed depositors as bank customers in retail banks which either remain solvent or go on to default between 2008 and 2012. I identify unexpected personal wealth losses, unrelated to an entrepreneur's firm, with investment losses in the stock market. I define investors as entrepreneurs who held investments in publicly traded retail banks outside of the bank in which they have a deposit account. Investors who are unexposed and exposed are determined by whether the bank they hold investments in remained solvent or defaulted during the financial crisis. Superscript $j$ therefore indexes whether the proxy is used for depositors or investors. I refer to these different sample groups as depositors and investors throughout the remainder of the analysis for simplicity. As exposed $_{i t}^{j}$ takes the value of one in post-default periods, $\gamma$ provides the average treatment effect of exposure after the default occurs compared to unexposed entrepreneurs (i.e. the difference-in-differences estimate) ${ }^{13}$

\footnotetext{
${ }^{13}$ In order to address potential serial correlation across time common in DD estimations with several pre- and post time periods as noted in Bertrand et al. (2004), I cluster all standard errors at the pre-crisis primary retail bank level.
} 
To illustrate these proxies, consider the following relationships;

$$
\begin{aligned}
\text { credit }_{i t} & =\sigma_{t}+\tau_{i}+\beta_{1} \text { exposed depositor } \\
i t & +\eta X_{i t}+\epsilon_{i t} \\
\text { liquidity }_{i t} & =\sigma_{t}+\tau_{i}+\beta_{2} \text { exposed } \text { investor }_{i t}+\eta X_{i t}+\epsilon_{i t}
\end{aligned}
$$

Equation 3 specifies an entrepreneur's access to debt financing. Customers of exposed retail banks held a personal deposit account at a bank which was unlikely to be able to supply additional credit to its client base in the short run following the onset of the crisis. These customers experienced their bank default and become taken over by Finansiel Stabilitet (FS), a Danish state-owned banking organization. These state-induced takeovers were initiated relatively discreetly in order to prevent banking runs and a speculative environment.

Immediately following the bankruptcy announcements, customers were directed to alternate retail banking branch locations to facilitate daily operations. In the medium term, the defaulted banks were supported by the state and day-to-day activities returned to a pre-bankruptcy norm. Previously, FS maintained a passive role in advising banks on their borrowing and lending arrangements. Once the affected banks began default discussions, FS took an active role in all activities of the exposed banks in an effort to provide security to depositors. Deposits of exposed bank customers were guaranteed by the state, and therefore the bank defaults had a limited effect on personal wealth holdings. ${ }^{14}$ However, the default of an entrepreneur's bank may directly affect the entrepreneur's ability to access capital in the form of personal bank loans. Additionally, customers of default banks may choose to move their account to another, more stable bank. If a small business owner moves to a new bank this may impede his or her ability to borrow, as it is well documented that borrower-lender relationships affect credit availability, term rates, and collateral requirements (Petersen and Rajan (1994); Berger and Udell (1998)).

Equation 4 studies the relationship between exposure to retail bank defaults and entrepreneurs' liquidity position. As an attempt to increase capital stocks, many retail banks in Denmark followed an expansionary policy consisting largely of selling stock to individual investors since the year 2000 (Danish Financial Supervisory Authority (2009)). These investments were common among investors, as described in Andersen et al. (2016); more than 60 percent of all investors held these assets in their portfolio. As these banks defaulted, the value of their traded shares rapidly declined until they held zero value and exposed investors to additional losses in a declining market.

To demonstrate, the top panel of Figure 1 plots a simple index of market returns in

\footnotetext{
${ }^{14}$ Depositor insurance in Denmark is provided by The Guarantee Fund for Depositors and Investors and guarantees $100 \%$ deposits up to 750,000 DKK (100,000 EUR). Notably relevant for this study, the Danish government decided to provide unlimited guarantees to depositors from October 5, 2008 to September 30, 2010.
} 
$\log$ terms of different types of investments held in the portfolios of market participants. The gray line, plots the average market returns of all equities outside of the Danish banking sector over time. The black solid line plots the returns of the equities of retail banking institutions which defaulted throughout the crisis, whose total value eventually diminishes to zero. These equities were eventually delisted from the Copenhagen Stock Exchange (CSE). Finally, the dashed black line plots the market returns for unexposed bank investors. These retail banking equities remained solvent throughout the crisis, and while their value decreased in comparison to all other equities, they retained a significant portion of their value compared to defaulting banks. Comparing the difference between the solid and dashed black lines serves as variation in personal liquid wealth losses, while holding constant the investment style of the investor. In fact, as shown in the bottom panel of Figure 1, the ex-post returns for a market-capitalization weighted portfolio of retail bank stocks which remain solvent compared to a portfolio bank stocks which end up in default had near identical risk and market returns in the 36 months preceding the financial crisis. The figure plots the distribution of monthly returns for the two portfolios containing retail banking stocks weighted by market capitalization from January 2005 to December 2007. ${ }^{15}$ A Kolmogorov-Smirnov test suggests that the distributions of monthly returns are not statistically different from each other, not surprising considering the timeseries correlation of monthly returns between the two portfolios is more than 90 percent.

For the average investor, these delisted investments led to sizable losses of liquid wealth. Appendix A.3 provides a tabulation of the distribution of losses for unexposed and exposed investors. The table states the mean, 25th, 50th, and 75th percentiles of total investment losses, total losses as a percentage of savings, as a percentage of liquid wealth, and as a percentage of net wealth. The table shows that on average, unexposed bankinvestor entrepreneurs lost 49,700 DKK (\$9,000 USD) in the declining market following the financial crisis, while exposed entrepreneurs lost on average 343,800 DKK $(\$ 62,500$ USD), equal to 30 percent of pre-crisis savings, or 22 percent of financial wealth.

In general, this identification strategy has several strengths. Firstly, for small businesses, personal and business expenditures are likely to overlap considerably, but stock investments are generally a financial instrument held in personal accounts and separately from an entrepreneur's firm. Therefore a shock to personal investments serves as an ideal proxy for understanding the effect of changes in personal financial liquidity on firm performance. Secondly, because variation comes from the specific bank, and not in the type of investment, I compare investors with similar investment styles and portfolios with similar risk-return structures who are exposed to idiosyncratic variation from the delisted

\footnotetext{
${ }^{15}$ December 2007 is an accepted starting date for the Great Recession (NBER), however similar distributional plots for varying time periods show qualitatively the same result, as does using an equally weighted portfolio.
} 
equities. Finally, these investments made up a significant fraction of the liquid wealth held by entrepreneurs in the sample. It should also be noted that the related literature has shown that individual investors are likely to be under-diversified, hold on to losing investments, invest in local assets, and are sluggish to update their portfolio or to realize returns. ${ }^{16}$ This suggests that it is not surprising, per se, that individuals may have let their portfolios containing defaulting bank stocks diminish instead of actively rebalancing away from these assets.

\subsection{Descriptive Characteristics of Bank Depositors and Investors}

The validity of estimates obtained by Equation 2 rests on the assumption that entrepreneurs who are exposed to banking defaults are similar to unexposed entrepreneurs, and selection into these two groups is near random. Therefore I pay particular attention to testing for differences in observable characteristics between entrepreneurs, controlling for fixed and time-varying demographic and financial characteristics, and examining the common pre-crisis trend in outcomes.

Table 2 focuses on the depositor sample of entrepreneurs in 2006 and compares entrepreneurs whose primary retail bank goes on to default during the financial crisis with entrepreneurs whose retail bank remains solvent. Column 4 presents the differences between exposed and unexposed depositors and the results of an unpaired $t$-test. In terms of observable demographic and financial characteristics exposed and unexposed entrepreneurs appear to be similar. Entrepreneurs who later become exposed to their retail bank defaulting are slightly more likely to be married, but the economic significance of this difference is questionable. In Table 3, I focus on a sample of entrepreneurs who invest in retail bank stocks outside of their own bank prior to the financial crisis. Columns 3 and 4 show that demographic, financial, and portfolio characteristics of unexposed and exposed investors are incredibly similar, with the differences and significance of the two groups displayed in Column 5. Column 5 suggests that the differences between the two groups is economically and statistically insignificant. This includes important indicators of background consumption such as mortgage loan-to-value, non-mortgage bank debt, and number of children. It also includes measures of investment style and risk taking such as the number of assets in an entrepreneur's portfolio and their allocation of financial wealth in risk-bearing assets. In total, Tables 2 and 3 suggest that the samples of entrepreneurs are well balanced.

In addition, Table 4 tests for correlation between entrepreneurship and bank and investment choice across a more general sample. In Columns 1-4 the sample consists of all

\footnotetext{
${ }^{16}$ Please see Barberis and Thaler (2003), Kaustia (2010), and Andersen et al. (2016) for related literature reviews.
} 
individuals in 2006, while in Columns 5 and 6 the sample consists of bank investors. The dependent variable is an indicator variable which takes the value of one if the individual is an entrepreneur in the year 2006. The variable of interest is bank that later defaults, which designates a retail bank which goes on to default during the financial crisis. If entrepreneurs were systematically selecting into retail banks which were destined to default, this would be problematic for my identifying assumptions. Coefficients state the odds ratio from a logistic regression. Moving across columns while adding demographic control variables there seems to be no systematic correlation between entrepreneurship and having a retail bank which goes on to default in the years following the financial crisis. In Columns 5 and 6 the variable of interest is bank investment default, which indicates an investment in a bank which goes on to default during the financial crisis. Again, this variable tests if there is observable correlation between investment choice for entrepreneurs prior to the financial crisis. The lack of significant cross-sectional heterogeneity suggests that the balance sheet of retail banks may not have necessarily been an important selection criteria among retail bank customers and investors prior to the financial crisis. ${ }^{17}$

Previous literature suggests that banks and their customers often form relationships which likely benefit both parties in future transactions. Borrowers with longer banking histories and thus stronger relationships benefit from greater credit availability and lower collateral requirements (Petersen and Rajan (1994); Berger and Udell (1995)). Lenders also benefit, banks with prior relationships to a borrower have a much higher likelihood of securing subsequent loan business from the borrower compared to a new borrower lacking such a relationship (Bharath et al. (2007)). Panel A of Table 5 suggests that retail banks in Denmark form such relationships with customers and banking choice may be sticky. The table shows the unconditional probability that a bank customer in a given year remains a customer of the same bank in the following year. Column 1 focuses on customers of the 5 largest retail banks, Column 2 excludes the five largest retail banks and Column 3 features customers of banks which go on to default during the financial crisis. The table shows that prior to the financial crisis the rate of continuing a banking relationship is approximately 90 percent. Moreover, this proportion does not significantly vary between customers at different types of banks. In Column 3, it is clearly shown that as the financial crisis unfolds, banks which default are associated with an increased separation rate between deposit customers and their banks.

Panel B of the table simply states the cumulative proportion of entrepreneurs who remain in their pre-crisis bank. Part of the aggregate separation may be mechanical due to the bank ceasing to exist. However, as the total proportion of customers who remain with

\footnotetext{
${ }^{17}$ Internet Appendix Table IA.1 provides bank level characteristics of the main types of banks in Denmark.
} 
a defaulted bank from 2005 to 2012 is near 15 percent (also shown graphically in Figure 2), a significant number of customers remain in a bank even after it has defaulted and remains in a state of resolution. The majority of exposed customers switched into a new bank, and given the previous literature on relationship banking, were likely impeded by a lack of historical relationships in borrowing from the new bank. Table 5 also shows perhaps more surprisingly, that as banks default, customers of other, similar banks (Column 2) remain account holders in those banks. This suggests some level of inertia in bank choice as customers refrain from moving their account to one of the largest banks which could potentially be deemed to be more safe as the financial crisis progressed.

\section{Results}

\subsection{The Effect of Bank Defaults on Channels of Financing}

How does exposure to retail bank defaults contribute to the hypothesized channels of personal financing? Table 6 outlines the results from Equations 3 and 4 . Columns 1 and 2 test the relationship between debt financing and exposure to bank defaults for the depositor sample of entrepreneurs. The sample consists of individuals who were entrepreneurs at any point prior to 2007. As personal loans play a large role in debt financing for small firms, a natural proxy for credit $_{i t}$ is the total personal bank loan stocks of an individual entrepreneur. Personal bank debt is measured in 1,000 DKK at year-end and includes all personal bank loans, credit card debt, and student loans. I focus the sample in Table 6 on entrepreneurs who own substantial housing assets (approximately 72 percent of the sample) in order to mitigate the role of small banking loans aimed to facilitate initial housing purchases. ${ }^{18}$ Additionally, the sample focuses on bank customers who do not hold equity investments in bank stocks and are therefore unexposed to related losses. The variable of interest is exposed depositors which indicates if an entrepreneur is a bank customer at a bank which defaults and takes the value of one in the periods after the default. Columns 1 and 2 suggest that after exposure to a bank default, depositors on average hold over 70,600 DKK (\$12,800 USD) less in bank loans, a substantial decrease in personal borrowing. This result contributes to contemporaneous research on banking shocks and imputed measures of consumption for non-entrepreneurs, for example Jensen and Johannesen (2015) find similarly that Danish customers of distressed banks reduced consumption and borrowing after the financial crisis. ${ }^{19}$

\footnotetext{
${ }^{18} \mathrm{In}$ an unreported analysis I test this on the full sample and find qualitatively similar results.

${ }^{19}$ The authors find a decrease of approximately 7,300 DKK at a mean value of 141,000 DKK, or a $5.2 \%$ effect for customers of banks with an above median ratio of loans to deposits. For entrepreneurs of default banks, I find a similar effect but much larger in levels, i.e., 70,600 DKK decrease at a mean value of 1,557,800 DKK or $4.5 \%$.
} 
Moving first to Columns 7 and 8, I test the relationship between default exposure and personal liquid wealth as outlined Equation 4. The dependent variable is the log of liquid wealth holdings at year end. Liquid wealth consists of the sum of year-end market value of stocks, bonds, and bank deposits. As in the previous columns the sample consists of all individuals who are or were entrepreneurs at any period before 2007, in this case the sample is restricted to investors who held retail bank stock investments outside of the bank which they were a deposit customer at any time between 2005-2007. The variable of interest is exposed investor which provides the effect of a banking default on liquid wealth holdings compared to similar entrepreneur-investors unaffected by defaulting bank stocks. Column 8 includes individual-entrepreneur fixed effects. The coefficient is significantly estimated at approximately -0.32 suggesting that investors with investments in banks which default are exposed to substantial losses in their liquid wealth. On average, exposed investors hold $32 \%$ less liquid wealth after their bank defaults compared to investors who held investments in retail banks which remain solvent. After controlling for fixed-effects and the time trend, this is an approximate average reduction of 234,000 DKK $(\$ 42,000$ USD).

Finally, Columns 3-4 and 5-6 show that the hypothesis laid out earlier holds relatively well. Exposed depositors are less affected by their liquid wealth assets, but largely in personal debt via their access to bank credit. Similarly, exposed investors are affected via their supply of liquid wealth rather than their access to bank lending. Figure 3 plots these analyses in an event study allowing one to verify assumptions about similar slopes and the common trend between exposed and unexposed groups. The top panel plots a dynamic model of the specification in Column 2 (left) and Column 4 (right). The plotted coefficients represent exposed $d_{i}^{j} \times$ year $_{t}$ indicating the interaction between exposure to a retail bank defaulting and the time-trend. This provides the difference in borrowing (left) and liquidity (right) between unexposed and exposed bank depositors at each year leading up to the financial crisis until 2011. The bottom panel plots the same analysis for bank investors, i.e., Column 6 (bottom-left) and Column 8 (bottom-right). The figures show that pre-crisis, the difference between exposed and unexposed entrepreneurs is not significantly different from zero, confirming assumptions about the common pre-trend. For bank depositors, exposed entrepreneurs decrease their borrowing post-crisis however hold a similar pattern of liquidity compared to unexposed entrepreneurs. For investors, the inverse holds: exposed entrepreneurs significantly decrease their liquidity position, however remain unaffected in their level of borrowing. ${ }^{20}$

\footnotetext{
${ }^{20}$ Internet Appendix IA.2 presents this model in full detail.
} 


\subsection{Firm Exit and Access to Debt Financing}

The previous section shows that bank depositors exposed to their own personal bank defaulting are more likely to switch banks and take on less personal bank debt. As debt finance is an important characteristic of small businesses, this exposure may have had significant effects on a firm's survival.

In Table 7 I investigate this relationship as outlined in Equation 2. The dependent variable is an indicator for exiting entrepreneurship, conditional on being an entrepreneur in the current period. The main variable of interest is exposure to bank default which indicates entrepreneurs with exposure to their primary retail bank defaulting. The variable takes the value of one if year $t$ is after the year of default for exposed entrepreneurs and zero if otherwise. Year and individual-entrepreneur fixed effects, $\alpha_{t}$ and $\rho_{i}$, account for differences across types of entrepreneurs over time. $X$, a vector of time-varying individual demographic and financial characteristics includes log wealth, log income, and if the entrepreneur has a child or purchases a house in year $t .{ }^{21}$ Because of the staggering of the banking defaults over time, entrepreneurs who go on to experience a default later, are included as a control group for earlier defaults.

Columns 1-4 begin by considering a full sample of entrepreneurs who are exposed and unexposed to the banking defaults. In Column 1 the average effect from exposure to a primary retail bank defaulting increases the probability of exiting entrepreneurship by 1.6 percentage points and is marginally significant at the 90 percent level. As discussed previously, there were a number of troubled banks, which rather than defaulting, found themselves in private merger and acquisition arrangements. Entrepreneurs exposed to this variation serve as a natural placebo test. If the default of a small business owner's retail bank inhibits their ability to take on debt as shown previously, a retail bank which results in a merger likely results in less of a disruption to personal borrowing. Effected bank depositors were integrated with an established bank, and were arguably less impacted in their ability to take on personal debt, as the relationship between borrower and lender was more likely to remain intact. The variable exposure to bank merger takes the value of one for entrepreneurs whose retail bank merged with another established retail bank in post-merger years. The effect of a bank merger should have a limited effect on available bank credit, and as expected does not have a significant effect on the firm's survival rate. This supports evidence from (Sapienza (2002)) who shows that in-market mergers have a positive effect on small businesses. In Column 3 and 4 the two exposure variables are

\footnotetext{
${ }^{21}$ In specifications without individual fixed effects $X$ includes age, age ${ }^{2}$, male, marriage status, education length in years, log wealth, log income, and child in the household, financial education, stock market participation, holding a positive loan balance, receiving unemployment benefits, holding positive housing wealth balance (in either debt or equity), and if the individual is an immigrant. In these specifications, I also control for the year that the firm was established.
} 
jointly estimated with and without individual-entrepreneur fixed effects. The inclusion of individual-entrepreneur fixed effects increases the average treatment effect of a default personal bank, suggesting that exposed entrepreneurs are approximately 2.5 percentage points more likely to exit from their firm relative to comparable unexposed entrepreneurs. This effect is economically meaningful as the average rate of exit is 19 percent. At the same time, exposure to retail banks which result in merger agreements with better-off banks do not increase firm exit.

The full sample specification in Columns 1-4 may be confounded by the fact that individuals who lose access to personal bank loans may be also be affected by losses in personal wealth stemming from the banking defaults. In Columns 5-8 I therefore remove from the sample entrepreneurs with investments in banks that eventually default, as the changes in personal financial wealth stemming from changes in investments may be a confounding factor to their firm's financial decisions. ${ }^{22}$ Once removing these individuals and considering solely the effect of changes in access to credit, Column 8 suggests that exposure to retail banks which default do indeed increase the probability of firm exit.

Similar research from the United States uses bank merger and acquisition activity following banking law liberalization. Results suggest that bank-branch closures reduce small business lending (Berger et al. (1998); Nguyen (2014)) and decrease employment (Greenstone et al. (2014)). However, Black and Strahan (2002) find a positive effect of banking consolidation on entrepreneurial activity, arguing that larger bank's diversification strengths may outweigh smaller bank's relationships strengths. Strahan and Weston (1998) find that mergers have little effect on small business lending, and if anything the relationship may be positive. Sapienza (2002) uses individual loan contract data on small businesses in Italy and finds that borrowing and lending rates increase after small mergers but decrease after large mergers.

Compared to the existing literature, this analysis focuses on the personal accounts of entrepreneurs and is at the individual firm owner-level rather than that of the firm. Therefore, a firm owner may have his or her own personal savings held in an affected bank, while the firm's finances may be held at a different bank. However, given the small size of firms in the sample, ${ }^{23}$ firm owners may hold their personal and business accounts in the same local banking institution. In addition, the above studies based on aggregated data which find a decline in small business activity may be confounded by a decrease in lending to individuals from the general population who would like to become entrepreneurs rather than established or existing firms. To that end, in Appendix A.4 I

\footnotetext{
${ }^{22}$ I should note that if the sample is restricted to entrepreneurs who never invest in any stocks or mutual funds the significance of the result fades, however this sample selection is too restrictive as more than $35 \%$ of all small business owners held an investment portfolio in 2006 .

${ }^{23}$ The median number of employees in firms in my sample is 3, as noted in Appendix A.2.
} 
test the effect of an individual's primary retail bank defaulting on his or her propensity to enter entrepreneurship. Here I find an approximately $0.9 \%$ decrease in the probability to entering entrepreneurship after the bank default, perhaps more comparable to the existing literature.

A challenge is to establish whether the banking defaults affected small business owners via a channel of consumer credit supply or through a demand shock which contributed to firm closure. I address this in Table 8 by controlling for the local area in which effected entrepreneurs are located. In Columns 1 and 4 the sample contains exposed entrepreneur depositors matched with unexposed entrepreneurs in the same municipality. Columns 2 and 5 match exposed entrepreneurs to unexposed entrepreneurs in the same parish. Parishes are ideal for this analysis as they present a reasonably small local area and essentially allow for matching at the neighborhood level. The median parish in in 2006 had a total population of only 1,107 individuals. Matching is based on 5 nearest neighbor exact matching on municipality or parish, five-year age cohort, pre-crisis wealth, gender, and marital status. Finally, in Columns 3 and 5 I focus on an exclusive subsample of entrepreneurs whose firm is located in a municipality outside of the municipality in which they reside in. Matching exposed and unexposed entrepreneurs in tight geographic locations allows me to hold constant any change in local market demand and isolate the effect of changes in credit supply. The coefficients of interest across columns reveal a highly similar story as to the effect shown in the previous table in magnitude.

\subsection{Firm Exit and Changes in Personal Wealth}

As demonstrated in Table 7, disruptions in entrepreneurs' ability to obtain personal loans may have a negative impact on firms' survival via a channel of debt financing. In the years following the financial crisis and in the face of weakened consumer demand, additional personal wealth losses may limit the ability of firm owners to supply personal equity to their firms especially for small businesses operating at the margin. This could increase the probability that entrepreneurs shut down their firms either due to a lack of ongoing capital, or to diversify their streams of income.

To analyze the effect of personal losses to liquid wealth on firm exit rates, I again turn to the econometric model specified in Equation 2. In this case, exposed $d_{i t}^{j}$ now proxies changes in liquidity with investment losses from delisted bank stocks due to their default. In Table 9 the dependent variable is an indicator variable for exiting entrepreneurship, conditional on being an entrepreneur in the previous period. The variable personal wealth losses takes the value of one if year $t$ is after the bank default year for the exposed group of investors and provides the average difference in the probability of firm exit after 
investment losses compared to unexposed bank-investor entrepreneurs. In Columns 1 and 2 the sample is unrestricted to all exposed and unexposed bank-investor entrepreneurs. The coefficient of the variable personal wealth losses suggests that entrepreneurs who were exposed to above median liquid wealth losses are approximately 5.4 percentage points more likely to exit from entrepreneurship compared to other bank-investor entrepreneurs unaffected by wealth losses. In Column 2 adding individual fixed effects slightly increases the estimate to 5.8 percentage points. This is an economically meaningful result, given a mean pre-crisis rate of exit of 16 percent. A 5.8 percentage point increase therefore corresponds to a marginal effect of 36 percent.

In Columns 3 and 4 entrepreneurs who hold investments in their own retail bank are excluded in order to disentangle the effects of loss of access to debt financing and losses in personal wealth. As expected, removing these individuals from the sample increases the average effect. Exposed entrepreneurs are approximately 6 percentage points more likely to exit from their firm in the years following the liquidity losses. To further distinguish between these two channels, in Columns 5 and 6 the sample contains entrepreneurs who either lost access to their retail bank, or lost liquidity due to wealth losses from default bank investments. Unexposed entrepreneurs have a retail bank which defaulted, therefore they lose potential access to debt finance and hold investments in other retail banks which do not default. Exposed entrepreneurs on the other hand have a retail bank which remains solvent, thus they continue to have access to debt finance, however they hold investments in a retail bank which defaults. This sample provides a powerful indication of the effect on wealth losses, as it holds constant the sample of investors with similar investment styles and compares bank-investors who lost access to debt finance compared to entrepreneurs who only lost financial wealth. The coefficient of the difference-in-differences variable suggests that entrepreneurs who lost liquid wealth are approximately 6 percentage points more likely to exit from their venture after experiencing the loss in liquidity. ${ }^{24}$

To verify the pre-crisis common trend between exposed and unexposed investors I plot a dynamic version of the model in Figure 5. Panel A plots the effect of retail bank default exposure on the effect of firm exit for the depositor sample discussed in the previous section. Panel B plots the interaction term between exposed $_{i}^{j}$ and yearly time dummies stemming from Column 4 in Table 9. The dynamic version of this model is shown in detail in Column 2 of Internet Appendix IA.3, along with a Wald test of joint significance for pre- and post-crisis time periods. The results suggest that pre-crisis, the

\footnotetext{
${ }^{24}$ The results presented thus far are also robust to alternative definitions of entrepreneurship. In an unreported analysis I create a dataset consisting of entrepreneurs and self-employed individuals and find qualitatively similar results. If the sample consists of only self-employed individuals, the effect of bank defaults and investments losses fades. This can potentially be explained if self-employed individuals are more likely to be consultants and/or work in less capital intensive businesses.
} 
difference in the probability of exit for exposed and unexposed entrepreneurs does not statistically deviate from zero, however post-crisis the the effect of liquidity losses has a large and statistically significant effect on probability of firm exit. To summarize, Table 9 suggests that losses in liquidity significantly increase the rate of entrepreneurial exit by roughly 5 to 6 percentage points, while the effect remains stable across samples and specifications. $^{25}$

In order to examine the heterogeneous effects of personal wealth losses on entrepreneurship, in Table 10 I split the sample by the length of time the firm has been in operation. Columns 1-3 focus on a sample of established entrepreneurs. Established entrepreneurs began their firm at any time prior to 2002, while in Columns 4-6 the sample consists of new entrepreneurs who started their first venture in the years prior to the financial crisis between 2002 and 2007. Each column represents the various samples discussed previously. Established entrepreneurs are far from immune to liquidity shocks. The average entrepreneur who started their firm well before the financial crisis is approximately 5 percentage points more likely to exit after losing an above median fraction of liquid assets. Columns 4-6 suggest that this effect is significantly greater for new entrepreneurs. Entrepreneur's who started their firm just prior to the financial crisis are 9-12 percentage points more likely to exit after experiencing liquidity losses. These results confirm existing cross-sectional evidence such as Berger and Udell (1995) and Robb and Robinson (2012), suggesting that owner provided equity may be more crucial for younger firms in the earlier stages of their life-cycle.

The results thus far suggest that an unexpected decrease in personal liquid wealth plays an important role in determining exit from entrepreneurship, especially for younger, less experienced small business owners. In order to quantify this effect across the distribution of losses, I turn to a DD specification with a continuous treatment variable.

$$
y_{i t}=\alpha_{t}+\sigma_{c}+\gamma\left(\text { exposed }_{i t} \times \phi_{i, 2006}\right)+\beta X_{i t}+\epsilon_{i t}
$$

where $\alpha_{t}$ and $\sigma_{c}$ are year and bank-treatment cohort fixed effects. Note that in specifications without individual-entrepreneur fixed effects the bank-treatment fixed effect is necessary to identify $\gamma$. As previous, exposed $_{i t}$ indicates entrepreneurs with exposure to investment losses stemming from retail bank investments and $\phi_{i, 2006}$ is the share of liquid wealth (i.e. the year-end market value sum of bank savings, bond holdings, and stock investments) invested in retail bank stocks prior to the financial crisis. $\gamma$ provides the

\footnotetext{
${ }^{25}$ In an unreported robustness check, I exclude from the sample investors who invest in the largest bank related equities in Denmark (e.g., Danske Bank) and focus the sample solely on local retail bank investors. This specification improves upon the match of exposed and unexposed investors. I find the results to be similar to the results presented.
} 
average treatment effect of exit from entrepreneurship for exposed entrepreneurs after the default of their bank investment at varying levels of pre-crisis investment in stocks which go on to default. The results from this specification are presented graphically in Panel A of Figure 4, showing the effect of the size of lost investment on the probability of exiting. The $x$-axis plots the fraction of liquid wealth lost from an investment in a default bank for exposed entrepreneurs after the banking defaults. The left panel of the first figure includes all entrepreneurs while the right-hand size focuses solely on new entrepreneurs who started their establishment in the years before the financial crisis. The results suggest that the probability to exit is an increasing function of the size of lost wealth; when entrepreneurs experience a complete loss of their liquid wealth the probability that they exit from their firm increases by nearly 40 percent.

\subsection{Firm Exit Hazard Rates}

The results from the previous section suggest that exposure to liquid wealth changes have large effects on exit from entrepreneurial firms. However, there are several dimensions of the data that warrant additional analysis prior to making conclusions regarding firm survival. In previous linear specifications I estimated the probability of firm exit at year $t$, while controlling for the year that the entrepreneur started-up the firm. It may be more reasonable to estimate the survival or hazard rate of entrepreneurial-firm $i$, conditional on the length of time in years $\tau$ that the firm has survived. In this case, the Cox proportional hazard model is a reasonable choice as it allows estimation of the baseline hazard without making any assumptions about it's shape over time. ${ }^{26}$ In addition, the hazard class of models are particularly well suited to handle the right-censored nature of entrepreneurial firm survival and competing reasons for exit.

While the identification strategy outlined in Section 4 remains similar, the econometric model changes to the form,

$$
\lambda_{i}\left(\tau \mid \operatorname{exposed}_{i}^{j}, X\right)=\lambda_{i, 0}(\tau) \exp \left\{\beta_{1} \text { exposed }_{i}^{j}+\beta_{2} \text { after }_{t}+\gamma\left(\text { exposed }_{i}^{j} \times \text { after }_{t}\right)+X^{\prime} \beta\right\}
$$

where $\tau$ is the length in years entrepreneur $i$ has been the owner of the current firm. The coefficient $\gamma$, represents a shift in the baseline hazard, $\lambda_{i, 0}(\tau)$, due to bank default exposure either affecting the entrepreneur via debt financing or via his liquid wealth in time periods after the year 2008. $X$ is a vector of control covariates which includes indicator variables for the entrepreneur's municipality of residence. As in the linear

\footnotetext{
${ }^{26}$ In an unreported table, I estimate the model using a Weibull distribution which allows for duration dependence in the shape parameter $\rho$, i.e., whether the probability of firm exit is increasing or decreasing as $\tau$ increases. The results from the Weibull model suggest a slight positive duration dependence, and the hazard rates and standard errors are comparable to the results presented in Table 11.
} 
probability models, I allow the baseline hazard to vary between calendar year in order to identify $\gamma \cdot{ }^{27}$

There are two sources of left-censoring that need to be addressed. The first is that I exclude entrepreneurs who began their firm after 1990 and shut down prior to the study period beginning in 2002. This is a trivial exclusion as it occurs by construction. The second is more serious and pertains to entrepreneurs who started their firm prior to 1990 and remain entrepreneurs after 2002 such that they are included in the study period. Because of data limitations if entrepreneurs started their firm before 1990, I will only capture the start year as 1990. To address this source of data censoring I also present results of a subsample limited to entrepreneurs who began their firm after 1990 .

Table 11 presents the results of the model specified above. Columns 1-5 focus on the depositor sample of entrepreneurs while Columns 6-8 features the bank investor sample of entrepreneurs. In Column 1 the variable of interest is exposure to bank default which presents the coefficient $\gamma$. All exponentiated coefficients are presented as proportional increases or decreases to the hazard of firm exit relative to one. If the coefficient is greater (smaller) than one, the difference from 1.0 indicates the percentage increase (decrease) in the probability of exit given a one-unit increase in the explanatory variable. Thus, exposure to a retail bank closure because of its default increases the hazard of firm exit by approximately 11 percent. Columns 2 and 3 test the relationships of exposure to retail banks involved in merger and acquisition activity rather than default. As previously mentioned, this works as a placebo test and as expected, I find no effect on the hazard of exit from exposure to merger activity.

As in the linear probability model of Table 7, in Columns 4 and 5 I focus the sample on bank depositors only, thus removing entrepreneurs who may be impacted in their liquid wealth holdings via investments in the banks which they hold deposits. Column 5 accounts for the left-censoring issue that some entrepreneurs began their firms prior to 1990 by excluding these individuals. The results of Columns 4 and 5 confirm the results presented previously, once accounting for changes in financial wealth, exposure to bank defaults have an apparent but small effect on the probability of exit.

Columns 6-8 suggest that exposure to financial losses of the entrepreneur strongly influence the hazard of his or her firm. The coefficient of personal wealth losses suggests exposure to liquidity losses increases the probability of firm exit by 29 to 47 percent, in line with the effect presented in the previous linear specification.

\footnotetext{
${ }^{27}$ As demonstrated by $\mathrm{Ai}$ and Norton (2003) the coefficients of interaction terms in non-linear models do not translate directly to difference-in-differences estimates as in linear models. Instead, in non-linear estimations, difference-in-differences should be evaluated using the full underlying model. To account for this, I compute each coefficient as described based on the conditional probability including all covariates held at their mean values.
} 


\subsection{Post-Exit Outcomes}

The results thus far suggest that contractions in personal liquidity are linked to higher levels of exit for entrepreneurial firms throughout the Great Recession. However, entrepreneurial survival is challenging to measure for a number of reasons. On one hand, entrepreneurs in the sample are defined by employing at least one additional individual in the firm. Therefore, if changes in labor inputs occur at the intensive margin it may look like the entrepreneur is shutting down his venture, when actually he or she is downsizing. Secondly, the shutdown decision for an entrepreneur is complicated in the sense that entrepreneurs close businesses for a number of reasons. A venture may be abandoned in order to start a new, more promising venture, or the decision could in fact be driven by under-performance (Parker (2009)). Survey data from the US suggests that many entrepreneurs deemed their venture to be successful upon closure (Headd (2003); Bates (2005)) and only about 10-15 percent of entrepreneurial closures result in bankruptcy (Baird and Morrison (2005)). ${ }^{28}$

If firm owners were to close down their ventures in order to immediately start new ventures their employment designation in the administrative data would remain within the definition of entrepreneurship. If owners were to downsize their firm and move to a self-employed status without employing other individuals, this would be observantly equivalent to firm exit, given the previous definition of entrepreneurship. Ignoring these outcomes could potentially mislead the interpretation of the results. While the data does not allow one to determine if the exit was voluntary or out of necessity, for non-censored observations I observe the labor market activity of the entrepreneur after firm-exit. I therefore designate the below outcomes following firm-exit,

$$
\text { outcome }_{k}= \begin{cases}1 & \text { unemployment or labor market exit } \\ 2 & \text { enter salaried position in labor market } \\ 3 & \text { self-employment/downsize in the same firm } \\ 4 & \text { start-up new firm }\end{cases}
$$

The subhazard function of exit outcome $k$, is then given by the following,

$$
\hat{\lambda}_{i k}\left(\tau \mid \operatorname{exposed}_{i t}^{j}, X\right)=\hat{\lambda}_{i, k, 0}(\tau) \exp \left\{\beta_{1} \text { exposed }_{i}^{j}+\beta_{2} \text { after }_{t}+\gamma\left(\operatorname{exposed}_{i}^{j} \times \text { after }_{t}\right)+X^{\prime} \beta\right\}
$$

I estimate the above equation as specified in Fine and Gray (1999) which is the analogous to the Cox proportional hazard for competing risks in that it makes no assumption about the distribution of the baseline hazard function.

\footnotetext{
${ }^{28}$ See Parker (2009) for additional references.
} 
Table 12 presents the result of competing risk hazard regressions where the columns represent the various possible post-exit outcomes. In Column 1, entrepreneurs close their venture and enter into a state of unemployment or exit the labor market completely. In Column 2, entrepreneurs enter into a non-ownership, salaried position, at a new firm after exiting from their venture. In Column 3, entrepreneurs remain in the current venture, however either downsize their employees and/or take on a self-employment designation discussed in Section 3.1. Finally, in Column 4, entrepreneurs exit their venture to start up a new entrepreneurial firm. Panel A presents the results across the bank depositor sample and considers the effect of financing disruptions on each one of these outcomes, while taking into consideration the three remaining competing risk outcomes. The subhazard outcomes after changes in credit availability due to a retail bank defaulting show that there is a marginal effect where exposed entrepreneurs are more likely to predict exit to unemployment. For the remainder of the post-exit outcomes there is no significant difference between exposed and unexposed entrepreneurs.

In Panel B, I consider the effects of lost liquidity due to default bank investments on each of the four outcomes while treating each other outcome as a competing risk. If losses in liquidity effect an owners ability to supply equity investments to a firm, it is unlikely that exposed entrepreneurs will exit their venture in order to start-up a new venture. On the other hand if personal losses are substantial, an entrepreneur may withdraw equity from the firm to support previous commitments. Therefore, a firm owner may be more likely to seek an employment contract which could offer a more stable source of income. Panel B suggests that entrepreneurs exposed to liquidity losses are almost twice as likely to exit a firm and enter into a salaried labor contract compared to unexposed entrepreneurs. This suggests that size of the income shock is significantly large as it affects not only their decision to close their venture, but also their choice of future employment. As entrepreneurs in my sample are classified by employing others, it is unlikely that my results can be interpreted as Taylor (1999), who suggests that self-employment may be a transitory state between employment spells. In fact, Panel B shows that liquidity losses increase the probability that an entrepreneur downsizes or remains self-employed, and these results are both statistically significant.

\subsection{Intensive Margin Decisions}

As shown, changes in access to debt financing and personal wealth affect the extensive margin of firm operations. However, it is logical to assume that if disruptions affect the ability to supply capital to the firm rather than via some other channel, firm owners may attempt to reduce the variable costs associated with labor inputs prior to ceasing 
operations. In Table $13 \mathrm{I}$ focus on changes at the intensive margin for small business owners. I ask if employers reduce employee headcount when facing an unexpected decline in access to debt financing, or a decrease in their personal liquid wealth.

Columns 1 and 2 consider the effect of losses in access to debt financing due to the default of the entrepreneur's retail bank, while Columns 3 and 4 focus on the effect of losses in personal liquid wealth. In both cases, the sample represents entrepreneurs who employ at least one other individual in year $t$, and for this analysis, I exclude entrepreneurs who employ a number of employees greater than the 99th percentile. The results from this table suggests that wealth losses drive changes at the intensive margin, however changes in access to financing have a limited effect. This is in contrast to a recent literature examining the effect of credit market disruptions on employment (Chodorow-Reich (2014). However, Greenstone et al. (2014)), finds a limited effect in smaller businesses perhaps more comparable to this analysis. On the other hand, personal losses in liquid wealth holdings have a large and significant effect. Firm owners who lose a significant source of personal liquidity operate smaller firms after they experience personal losses. ${ }^{29}$ On average, exposed employers reduce their number of employees by approximately 0.26 to 0.72 employees after experiencing financial wealth losses. This is a substantial decrease considering the average number of employees in these small firms is $4.8 .^{30}$

\subsection{Heterogeneity in Households}

The decision to exit from a small business is likely to vary considerably from household to household. Table 14 questions whether the relative importance of entrepreneurial income within the household plays a role in exit from firms for exposed entrepreneurs. The dependent variable continues to be an indicator variable for exiting entrepreneurship, conditional on being an entrepreneur in the last period. The variables exposure to bank default and personal wealth losses are defined as previous. Columns 1 and 2 focuses on the depositor sample of entrepreneurs while Columns 3 and 4 focus on the investor sample. In Columns 1 and 3 the sample consists of married entrepreneurs whose income share to the total household is less than 50 percent. In Columns 2 and 4 married entrepreneurs income share within the household is greater than or equal to 50 percent. For bank depositors, it appears that the relative share of income to the household does not impact firm exit. For bank investors on the other hand, firm owners who contribute a large share of income to the total household, are much more likely to exit from their firm after experiencing personal wealth losses from defaulting bank investments. The effect of losses in personal

\footnotetext{
${ }^{29}$ This effect could be driven by employers actively reducing staff, by employers simply choosing not to renew employment contracts, or alternatively by employees selecting out of certain ventures.

${ }^{30}$ Internet Appendix IA.3 presents the dynamic version of Table 13.
} 
wealth causes firm exit for owners whose businesses have a larger relative importance in the households' total income. This result is shown graphically in Panel B of Figure 4.

Similarly, in Table 15, the sample is divided into terciles such that Column 1 (2) (3) includes the bottom (middle) (top) third of the distribution. Panel A separates this for net wealth while Panel B separates total sources of debt. Again, for the depositor sample there appears to be a limited effect of heterogeneity across households on the propensity to exit from a firm once exposed to their own bank defaulting. For investors, the results from Panel A suggest that entrepreneurs outside of the top third of the distribution of wealth are more impacted by personal wealth losses. Panel B shows that investors with high debt are almost 10 percentage points more likely to exit from their firm after exposure to personal wealth losses from lost investments. These results suggest that, unsurprisingly, more financially constrained small business owners are affected by personal wealth losses.

\section{Alternative Mechanisms}

A robust finding of this analysis shows that large losses in personal wealth increase the rate of firm exit for small business owners. The main channel that has been discussed so far suggests that this casual effect is rooted in limited financing as a barrier to firm survival. However, this liquid wealth shock may also cause changes in risk taking behavior which in turn could affect the desire of an individual to continue with an entrepreneurial firm. There is a large literature that suggests that entrepreneurs may perceive risk differently from salaried individuals. ${ }^{31}$ I cannot exclude the possibility that large wealth losses affect the beliefs entrepreneurs hold about future sources of risk. This is especially difficult to disentangle empirically, for example Andersen et al. (2016) show that the effect of investment losses and portfolio inertia are observantly equivalent, therefore it is difficult to separate the experience shock from changes in risk taking particularly when investors are inactive. Nonetheless, Andersen et al. (2016) find that negative experiences in the stock market made individually do indeed reduce future financial risk taking.

In particular, two results presented thus far suggest that alternative mechanisms may be of importance. Firstly, large investment losses seem to drive entrepreneurs into salaried labor rather than into a new entrepreneurial venture. This could suggest that these small business owners are less comfortable taking on additional income risk in the future and therefore seek an alternative occupation. Relatedly, exposed entrepreneurs who are breadwinners within the household are more affected by financial losses compared to

\footnotetext{
${ }^{31}$ See Åstebro et al. (2014) and Koudstaal et al. (2015) for recent discussions. In addition, recent evidence suggests that these differences may be attributable to entrepreneurs' willingness to risk losses (Koudstaal et al. $(2015))$.
} 
those who contribute a smaller share of income. This could suggest that small business owners may need to actively liquidate the firm in order to support commitments and not necessarily because their firm is constrained in capital. At the same time, changes at the intensive margin for small business imply that financing shocks have real effects aside from these other mechanisms. Likely, the results presented in this analysis are a combination of these factors and personal financing disruptions affect the survival of firms through a number of related mechanisms.

\section{Conclusion}

Much of the previous literature on financing for small businesses has focused on the initial starting conditions of entrepreneurs, liquidity constraints, and the capital structure of the firm. The previous research on how credit market disruptions affect firms focus on larger firms and shocks to commercial and business lending. In contrast, this paper studies how personal financing disruptions experienced directly by the individual entrepreneur can have large causal effects on the survival rate of their businesses during operations. I use detailed administrative data on individual entrepreneurs matched with data on their banking relationships and personal assets to estimate the effects of changes in access to debt financing and personal liquid wealth on firm performance and survival rates. The wave of banking defaults that occurred throughout the Great Recession in Denmark serves as variation between small business owners and their borrowing ability, as well as changes in personal liquid asset positions.

My results suggest that for established entrepreneurs, access to personal debt financing is an important attribute of firm survivorship. At the same time, a decrease in the personal liquidity of a small business owner substantially increases the hazard of firm exit. Losses of individual wealth affect intensive margin decisions as well, affected firm owners are more likely to employ fewer individuals after losses in personal wealth. Particularly in times of economic crisis, personal wealth and personal borrowing play a key role in entrepreneurial decision making. In the future, it will be interesting to examine how entrepreneurs are affected by changes in access to informal lending, and if changes in assets within the household, or social-networks of entrepreneurs affect their firm's outcomes. 


\section{References}

Adelino, M., S. Ma, and D. T. Robinson (2014). Firm age, investment opportunities, and job creation. Technical report, National Bureau of Economic Research.

Ai, C. and E. C. Norton (2003). Interaction terms in logit and probit models. Economics letters $80(1), 123-129$.

Andersen, S., T. Hanspal, and K. M. Nielsen (2016). Once bitten, twice shy: The role of inertia and personal experiences in risk taking. Working Paper.

Andersen, S. and K. M. Nielsen (2012). Ability or finances as constraints on entrepreneurship? evidence from survival rates in a natural experiment. Review of Financial Studies 25(12), 3684-3710.

Ashcraft, A. B. (2003). Are banks really special? new evidence from the fdic-induced failure of healthy banks. New Evidence from the FDIC-induced Failure of Healthy Banks (December 2003). FRB of New York Staff Report (176).

Åstebro, T., H. Herz, R. Nanda, and R. A. Weber (2014). Seeking the roots of entrepreneurship: Insights from behavioral economics. The Journal of Economic Perspectives 28(3), 49-69.

Baird, D. G. and E. R. Morrison (2005). Serial entrepreneurs and small business bankruptcies. Columbia Law Review, 2310-2368.

Barberis, N. and R. Thaler (2003). A survey of behavioral finance. Handbook of the Economics of Finance 1, 1053-1128.

Bates, T. (2005). Analysis of young, small firms that have closed: delineating successful from unsuccessful closures. Journal of Business Venturing 20(3), 343-358.

Bayus, B. L. and R. Agarwal (2007). The role of pre-entry experience, entry timing, and product technology strategies in explaining firm survival. Management Science 53(12), 1887-1902.

Berger, A. N., A. Saunders, J. M. Scalise, and G. F. Udell (1998). The effects of bank mergers and acquisitions on small business lending. Journal of financial Economics 50(2), 187-229.

Berger, A. N. and G. F. Udell (1995). Relationship lending and lines of credit in small firm finance. Journal of Business, 351-381.

Berger, A. N. and G. F. Udell (1998). The economics of small business finance: The roles of private equity and debt markets in the financial growth cycle. Journal of Banking \& Finance 22(6), 613-673.

Bertrand, M., E. Duflo, and S. Mullainathan (2004). How much should we trust differences-in-differences estimates? The Quarterly Journal of Economics 119(1), 249275 . 
Bharath, S., S. Dahiya, A. Saunders, and A. Srinivasan (2007). So what do i get? the bank's view of lending relationships. Journal of financial Economics 85(2), 368-419.

Black, S. E. and P. E. Strahan (2002). Entrepreneurship and bank credit availability. The Journal of Finance 57(6), pp. 2807-2833.

Blanchflower, D. G. and A. J. Oswald (1998). What makes an entrepreneur? To appear in Journal of Labor Economics 16(1), 26-60.

Brown, J. R., G. Martinsson, and C. J. Thomann (2015). What if firms could borrow more? evidence from a natural experiment.

Buchholst, B. V. and J. Rangvid (2013). Leading indicators of distress in danish banks in the period 2008-12. Danmarks Nationalbank Working Papers (85).

Chodorow-Reich, G. (2014). The employment effects of credit market disruptions: Firm-level evidence from the 2008-9 financial crisis. The Quarterly Journal of Economics 129(1), 1-59.

Cooper, A. C., F. J. Gimeno-Gascon, and C. Y. Woo (1994). Initial human and financial capital as predictors of new venture performance. Journal of business venturing 9(5), $371-395$.

Cowling, M., W. Liu, and A. Ledger (2012). Small business financing in the uk before and during the current financial crisis. International Small Business Journal 30(7), $778-800$.

Cowling, M., W. Liu, A. Ledger, and N. Zhang (2015). What really happens to small and medium-sized enterprises in a global economic recession? uk evidence on sales and job dynamics. International Small Business Journal 33(5), 488-513.

Danish Financial Supervisory Authority (2009). Rapport om salg af egne aktier, 2009. Report, Copenhagen Denmark.

Degryse, H., N. Masschelein, and J. Mitchell (2011). Staying, dropping, or switching: the impacts of bank mergers on small firms. Review of Financial Studies 24 (4), 1102-1140.

Evans, D. S. and B. Jovanovic (1989, August). An Estimated Model of Entrepreneurial Choice under Liquidity Constraints. Journal of Political Economy 97(4), 808-27.

Fairlie, R. W. (2013). Entrepreneurship, economic conditions, and the great recession. Journal of Economics \&5 Management Strategy 22(2), 207-231.

Fine, J. P. and R. J. Gray (1999). A proportional hazards model for the subdistribution of a competing risk. Journal of the American statistical association 94(446), 496-509.

Fracassi, C., M. Garmaise, S. Kogan, and G. Natividad (2013). How much does credit matter for entrepreneurial success in the united states? Working Paper.

Gan, J. (2007). The real effects of asset market bubbles: Loan-and firm-level evidence of a lending channel. Review of Financial Studies 20(6), 1941-1973. 
Gentry, W. M. and R. G. Hubbard (2004). Entrepreneurship and household saving. Advances in Economic Analysis 63 Policy 4(1).

Greenstone, M., A. Mas, and H.-L. Nguyen (2014). Do credit market shocks affect the real economy? quasi-experimental evidence from the great recession and'normal'economic times. NBER Working Paper Series, 20704.

Headd, B. (2003). Redefining business success: Distinguishing between closure and failure. Small Business Economics 21(1), 51-61.

Holtz-Eakin, D., D. Joulfaian, and H. S. Rosen (1994). Sticking it out: Entrepreneurial survival and liquidity constraints. Journal of Political Economy, 53-75.

Hvide, H. K. and J. Møen (2010). Lean and hungry or fat and content? entrepreneurs' wealth and start-up performance. Management Science 56(8), 1242-1258.

Iyer, R., J.-L. Peydró, S. da Rocha-Lopes, and A. Schoar (2014). Interbank liquidity crunch and the firm credit crunch: Evidence from the 2007-2009 crisis. Review of Financial studies, hht056.

Jensen, T. L. and N. Johannesen (2015). The consumption effects of the 2007-2008 financial crisis: Evidence from household-level data.

Jensen, T. L., S. Leth-Petersen, and R. Nanda (2014). Housing collateral, credit constraints and entrepreneurship-evidence from a mortgage reform. NBER Working Paper Series, 20583.

Kaustia, M. (2010). Disposition effect. Behavioral Finance: Investors, Corporations, and Markets 6(171), 791-812.

Khwaja, A. I. and A. Mian (2008). Tracing the impact of bank liquidity shocks: Evidence from an emerging market. The American Economic Review, 1413-1442.

Koudstaal, M., R. Sloof, and M. Van Praag (2015). Risk, uncertainty, and entrepreneurship: Evidence from a lab-in-the-field experiment. Management Science.

Lafontaine, F. and K. Shaw (2016). Serial entrepreneurship: Learning by doing? Journal of Labor Economics 34 (S2), S217-S254.

Moreira, S. (2016). Firm dynamics, persistent effects of entry conditions, and business cycles. Mimeo.

Moskowitz, T. J. and A. Vissing-Jorgensen (2002). The returns to entrepreneurial investment: A private equity premium puzzle? American Economic Review 92(4), 745-778.

Nanda, R. (2008, January). Cost of external finance and selection into entrepreneurship. Harvard Business School Working Papers 08-047, Harvard Business School.

Nanda, R. (2011). Entrepreneurship and the discipline of external finance. Harvard Business School Entrepreneurial Management Working Paper (11-098). 
Nanda, R. and J. B. Sørensen (2010, July). Workplace peers and entrepreneurship. Management Science 56(7), 1116-1126.

Nguyen, H.-L. (2014). Do bank branches still matter? the effect of closings on local economic outcomes. Working Paper.

OECD (2009). The impact of the global crisis on sme and entrepreneurship financing and policy responses.

Paravisini, D. (2008). Local bank financial constraints and firm access to external finance. The Journal of Finance 63(5), 2161-2193.

Parker, S. C. (2009). The Economics of Entrepreneurship. Cambridge University Press.

Peek, J. and E. S. Rosengren (2000). Collateral damage: Effects of the japanese bank crisis on real activity in the united states. American Economic Review, 30-45.

Petersen, M. A. and R. G. Rajan (1994). The benefits of lending relationships: Evidence from small business data. The journal of finance 49(1), 3-37.

Rangvid, J., F. Østrup, and P. Møgelvang-Hansen (2013). Den finansielle krise i danmark: Årsager, konsekvenser og læring. Technical report, Erhvervs-og Vækstministeriet.

Reid, G. C. (1991). Staying in business. International Journal of Industrial Organization $9(4), 545-556$.

Robb, A. M. and D. T. Robinson (2012). The capital structure decisions of new firms. Review of Financial Studies, hhs072.

Sapienza, P. (2002). The effects of banking mergers on loan contracts. The Journal of finance 57(1), 329-367.

Schnabl, P. (2012). The international transmission of bank liquidity shocks: Evidence from an emerging market. The Journal of Finance 67(3), 897-932.

Shane, S. and T. Stuart (2002). Organizational endowments and the performance of university start-ups. Management science 48(1), 154-170.

Statistics Denmark (2016). Statbank denmark, business demography. http://statistikbanken.dk/. (july 2016).

Strahan, P. E. and J. P. Weston (1998). Small business lending and the changing structure of the banking industry. Journal of Banking \& Finance 22(6), 821-845.

Taylor, M. P. (1999). Survival of the fittest? an analysis of self-employment duration in britain. The Economic Journal 109(454), 140-155.

Van Praag, M. C. (2003). Business survival and success of young small business owners. Small Business Economics 21(1), 1-17.

Zarutskie, R. and T. Yang (2015). How did young firms fare during the great recession? evidence from the kauffman firm survey. In Measuring Entrepreneurial Businesses: Current Knowledge and Challenges. University of Chicago Press. 
Table 1: Employment Choice and Summary Statistics

The following table reports summary statistics for all individuals in the sample in the year 2006. Column 1 presents all individuals in the sample and Column 2 includes self-employed individuals. Column 3 focuses on entrepreneurs that employ at least one other individual, while Column 4 focuses on individuals who are in traditional salaried labor employment or temporarily outside of the labor market. The last column presents the differences between salaried and entrepreneurial individuals in the sample. Age is measured in years for each individual in 2006. Married indicates if the individual is married in the year 2006. Number of children is the total number of children of any age currently living in the same household. University education is an indicator variable taking the value of one if an individual has a high school and university education. Total income measures the income received by the individual from all sources, while liquid wealth is the sum of bank deposits, stocks, and bonds at year-end 2006 market values, and bank deposits is year-end personal bank savings. Positive housing assets indicates if an individual owns real estate (market value greater than 500,000 DKK). Total value of property is the sum of current value debt and equity of all housing investments and Mortgage value is the year-end value of outstanding mortgage debt. Mortgage $L T V$ is the ratio of outstanding mortgage debt to total housing assets. Value of debt is the total outstanding value of debts. Bank loans is the value of retail banking loans. All amounts are in thousands at the year-end 2006 and deflated to year-2010 DKK. All variables are presented at the individual level unless otherwise indicated. Standard deviations are in parentheses and t-statistics are reported in brackets. ***,**, and * indicate significant at the 1,5 , and 10 percent levels, respectively.

\begin{tabular}{|c|c|c|c|c|c|}
\hline & \multicolumn{5}{|c|}{ Full sample } \\
\hline & $\begin{array}{l}\text { All } \\
(1)\end{array}$ & $\begin{array}{c}\text { Self-employ } \\
(2)\end{array}$ & $\begin{array}{l}\text { Entrepreneurs } \\
\text { (3) }\end{array}$ & $\begin{array}{c}\text { Salaried } \\
(4)\end{array}$ & $\begin{array}{c}\text { Differences } \\
(3)-(4)\end{array}$ \\
\hline Age & $\begin{array}{l}41.30 \\
(7.29)\end{array}$ & $\begin{array}{l}41.18 \\
(7.33)\end{array}$ & $\begin{array}{l}42.70 \\
(6.84)\end{array}$ & $\begin{array}{l}41.28 \\
(7.29)\end{array}$ & $\begin{array}{c}1.42^{* * *} \\
{[33.53]}\end{array}$ \\
\hline Male & $\begin{array}{c}0.51 \\
(0.50)\end{array}$ & $\begin{array}{c}0.57 \\
(0.49)\end{array}$ & $\begin{array}{c}0.75 \\
(0.43)\end{array}$ & $\begin{array}{c}0.50 \\
(0.50)\end{array}$ & $\begin{array}{l}0.25^{* * *} \\
{[86.46]}\end{array}$ \\
\hline Married & $\begin{array}{l}0.61 \\
(0.49)\end{array}$ & $\begin{array}{c}0.54 \\
(0.50)\end{array}$ & $\begin{array}{l}0.72 \\
(0.45)\end{array}$ & $\begin{array}{c}0.61 \\
(0.49)\end{array}$ & $\begin{array}{l}0.10^{* * *} \\
{[36.38]}\end{array}$ \\
\hline Number of children & $\begin{array}{l}1.10 \\
(1.09)\end{array}$ & $\begin{array}{l}1.07 \\
(1.18)\end{array}$ & $\begin{array}{l}1.36 \\
(1.18)\end{array}$ & $\begin{array}{l}1.10 \\
(1.08)\end{array}$ & $\begin{array}{l}0.26^{* * *} \\
{[41.88]}\end{array}$ \\
\hline University education & $\begin{array}{c}0.25 \\
(0.43)\end{array}$ & $\begin{array}{c}0.19 \\
(0.39)\end{array}$ & $\begin{array}{c}0.16 \\
(0.37)\end{array}$ & $\begin{array}{c}0.26 \\
(0.44)\end{array}$ & $\begin{array}{l}-0.10^{* * *} \\
{[-37.79]}\end{array}$ \\
\hline Total income & $\begin{array}{c}378.67 \\
(350.47)\end{array}$ & $\begin{array}{c}313.55 \\
(442.37)\end{array}$ & $\begin{array}{c}743.11 \\
(1750.47)\end{array}$ & $\begin{array}{c}376.85 \\
(232.52)\end{array}$ & $\begin{array}{l}366.26^{* * *} \\
{[186.47]}\end{array}$ \\
\hline Liquid wealth & $\begin{array}{l}139.81 \\
(321.17)\end{array}$ & $\begin{array}{l}197.59 \\
(556.46)\end{array}$ & $\begin{array}{c}451.80 \\
(927.53)\end{array}$ & $\begin{array}{c}128.57 \\
(260.51)\end{array}$ & $\begin{array}{l}323.23^{* * *} \\
{[191.98]}\end{array}$ \\
\hline Value of bank deposits & $\begin{array}{c}85.44 \\
(173.22)\end{array}$ & $\begin{array}{l}116.48 \\
(288.41)\end{array}$ & $\begin{array}{c}264.72 \\
(497.06)\end{array}$ & $\begin{array}{c}79.17 \\
(142.52)\end{array}$ & $\begin{array}{l}185.55^{* * *} \\
{[202.28]}\end{array}$ \\
\hline Positive housing assets & $\begin{array}{c}0.56 \\
(0.50)\end{array}$ & $\begin{array}{c}0.48 \\
(0.50)\end{array}$ & $\begin{array}{c}0.80 \\
(0.40)\end{array}$ & $\begin{array}{c}0.56 \\
(0.50)\end{array}$ & $\begin{array}{l}0.23^{* * *} \\
{[80.48]}\end{array}$ \\
\hline Total value of property & $\begin{array}{c}848.43 \\
(1487.39)\end{array}$ & $\begin{array}{c}1367.64 \\
(3107.50)\end{array}$ & $\begin{array}{c}3660.93 \\
(5963.21)\end{array}$ & $\begin{array}{c}747.31 \\
(842.85)\end{array}$ & $\begin{array}{l}2913.62^{* * *} \\
{[422.61]}\end{array}$ \\
\hline Mortgage value & $\begin{array}{c}534.22 \\
(996.30)\end{array}$ & $\begin{array}{c}805.02 \\
(1997.37)\end{array}$ & $\begin{array}{c}2508.57 \\
(4333.27)\end{array}$ & $\begin{array}{c}471.21 \\
(537.10)\end{array}$ & $\begin{array}{l}2037.36^{* * *} \\
{[432.23]}\end{array}$ \\
\hline Mortgage loan to value & $\begin{array}{c}0.68 \\
(0.67)\end{array}$ & $\begin{array}{l}0.66 \\
(0.57)\end{array}$ & $\begin{array}{c}0.76 \\
(1.09)\end{array}$ & $\begin{array}{c}0.68 \\
(0.66)\end{array}$ & $\begin{array}{c}0.08^{* * *} \\
{[18.92]}\end{array}$ \\
\hline Total value of debt & $\begin{array}{c}773.90 \\
(2976.72)\end{array}$ & $\begin{array}{c}1182.51 \\
(3961.26)\end{array}$ & $\begin{array}{c}4559.31 \\
(18565.95)\end{array}$ & $\begin{array}{c}662.51 \\
(1080.78)\end{array}$ & $\begin{array}{l}3896.80^{* * *} \\
{[236.86]}\end{array}$ \\
\hline Bank loans & $\begin{array}{c}204.71 \\
(1555.52)\end{array}$ & $\begin{array}{c}337.38 \\
(1903.17)\end{array}$ & $\begin{array}{c}1491.75 \\
(10046.86)\end{array}$ & $\begin{array}{c}167.37 \\
(536.28)\end{array}$ & $\begin{array}{l}1324.38^{* * *} \\
{[150.49]}\end{array}$ \\
\hline Observations & $1,643,542$ & 126,634 & 30,082 & $1,486,826$ & - \\
\hline
\end{tabular}


Table 2: Summary Statistics of Bank Depositors

The following table reports summary statistics for entrepreneurs in the sample in the year 2006. Column 1 presents all entrepreneurs in the sample, Column 2 focuses on unexposed entrepreneurs who have a retail banking institution in 2006 which did not default in the following financial crisis. Column 3 is comprised of exposed entrepreneurs who have a retail banking institution in 2006 which goes on to subsequently default in 2008-2012. The last column presents the differences between exposed and unexposed entrepreneurs. Age is measured in years for each individual in 2006. Married indicates if the individual is married in the year 2006. Number of children is the total number of children of any age currently living in the same household. University education is an indicator variable taking the value of one if an individual has a high school and university education. Total income measures the income received by the individual from all sources, while liquid wealth is the sum of bank deposits, stocks, and bonds at year-end 2006 market values, and bank deposits is year-end personal bank savings. Positive housing assets indicates if an individual owns real estate (market value greater than 500,000 DKK). Total value of property is the sum of current value debt and equity of all housing investments and Mortgage value is the year-end value of outstanding mortgage debt. Mortgage LTV is the ratio of outstanding mortgage debt to total housing assets. Value of debt is the total outstanding value of debts. Bank loans is the value of retail banking loans. All amounts are in thousands at the year-end 2006 and deflated to year-2010 DKK. All variables are presented at the individual level unless otherwise indicated. Standard deviations are in parentheses and t-statistics are reported in brackets. ${ }^{* * *},{ }^{* *}$, and $*$ indicate significant at the 1,5 , and 10 percent levels, respectively.

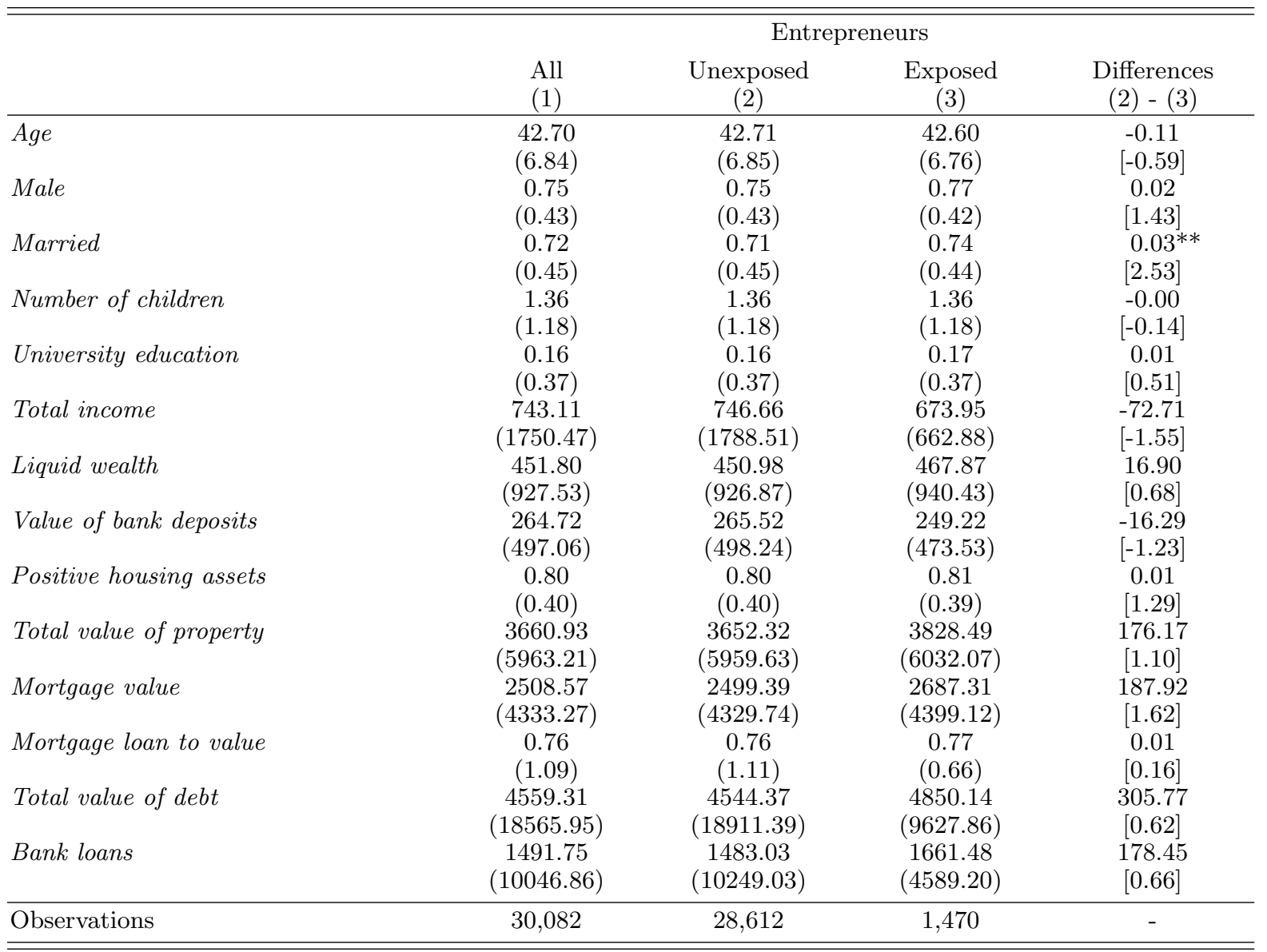


Table 3: Summary Statistics of Bank Investors

The following table reports summary statistics for all individuals in the sample in the year 2006. Column 1 presents all entrepreneurs in the sample, Column 2 focuses on all entrepreneurs who hold a positive amount of retail banking investments in 2006. Column 3 focuses on unexposed entrepreneurs who hold investments in retail banks in 2006 which did not default in the following financial crisis. Column 4 is comprised of exposed entrepreneurs who hold investments in retail banking institutions in 2006 which goes on to subsequently default in 2008-2012. The last column presents the differences between exposed and unexposed entrepreneurs. Age is measured in years for each individual in 2006. Married indicates if the individual is married in the year 2006. Number of children is the total number of children of any age currently living in the same household. University education is an indicator variable taking the value of one if an individual has a high school and university education. Total income measures the income received by the individual from all sources, while liquid wealth is the sum of bank deposits, stocks, and bonds at year-end 2006 market values, and bank deposits is year-end personal bank savings. Positive housing assets indicates if an individual owns real estate (market value greater than $500,000 \mathrm{DKK}$ ). Total value of property is the sum of current value debt and equity of all housing investments and Mortgage value is the year-end value of outstanding mortgage debt. Mortgage LTV is the ratio of outstanding mortgage debt to total housing assets. Value of debt is the total outstanding value of debts. Bank loans is the value of retail banking loans and Value of stock holdings is the market value of year-end stock holdings outside of pension contributions. Risk share is the fraction of liquid assets held in stock investments and Unique stocks in portfolio is the number of unique assets in the stock market portfolio including mutual funds. All amounts are in thousands at the year-end 2006 and deflated to year-2010 DKK. Bank loans and Total debt are winsorized at the 99th percentile. All variables are presented at the individual level unless otherwise indicated. Standard deviations are in parentheses and t-statistics are reported in brackets. $* * *, * *$, and $*$ indicate significant at the 1,5 , and 10 percent levels, respectively.

\begin{tabular}{|c|c|c|c|c|c|}
\hline & \multicolumn{5}{|c|}{ Entrepreneurs } \\
\hline & $\begin{array}{l}\text { All } \\
(1)\end{array}$ & $\begin{array}{c}\text { Bank investors } \\
(2)\end{array}$ & $\begin{array}{c}\text { Unexposed } \\
(3)\end{array}$ & $\begin{array}{l}\text { Exposed } \\
(4)\end{array}$ & $\begin{array}{c}\text { Differences } \\
(3)-(4)\end{array}$ \\
\hline Age & $\begin{array}{l}42.70 \\
(6.84)\end{array}$ & $\begin{array}{l}43.76 \\
(6.77)\end{array}$ & $\begin{array}{l}43.81 \\
(6.77)\end{array}$ & $\begin{array}{l}43.49 \\
(6.73)\end{array}$ & $\begin{array}{l}-0.32 \\
{[-1.43]}\end{array}$ \\
\hline Male & $\begin{array}{c}0.75 \\
(0.43)\end{array}$ & $\begin{array}{c}0.81 \\
(0.40)\end{array}$ & $\begin{array}{c}0.80 \\
(0.40)\end{array}$ & $\begin{array}{c}0.82 \\
(0.39)\end{array}$ & $\begin{array}{l}0.02 \\
{[1.27]}\end{array}$ \\
\hline Married & $\begin{array}{c}0.72 \\
(0.45)\end{array}$ & $\begin{array}{c}0.74 \\
(0.44)\end{array}$ & $\begin{array}{c}0.74 \\
(0.44)\end{array}$ & $\begin{array}{l}0.73 \\
(0.45)\end{array}$ & $\begin{array}{c}-0.02 \\
{[-1.04]}\end{array}$ \\
\hline Number of children & $\begin{array}{c}1.36 \\
(1.18)\end{array}$ & $\begin{array}{l}1.36 \\
(1.20)\end{array}$ & $\begin{array}{c}1.36 \\
(1.21)\end{array}$ & $\begin{array}{c}1.33 \\
(1.19)\end{array}$ & {$[-0.04$} \\
\hline University education & $\begin{array}{l}0.16 \\
(0.37)\end{array}$ & $\begin{array}{l}0.20 \\
(0.40)\end{array}$ & $\begin{array}{l}0.20 \\
(0.40)\end{array}$ & $\begin{array}{l}0.22 \\
(0.41)\end{array}$ & $\begin{array}{l}0.02 \\
{[1.12]}\end{array}$ \\
\hline Total income & $\begin{array}{c}743.11 \\
(1750.47)\end{array}$ & $\begin{array}{c}943.34 \\
(3135.85)\end{array}$ & $\begin{array}{c}912.97 \\
(1115.95)\end{array}$ & $\begin{array}{c}1128.19 \\
(7881.99)\end{array}$ & $\begin{array}{l}215.22 \\
{[0.88]}\end{array}$ \\
\hline Liquid wealth & $\begin{array}{c}451.80 \\
(927.53)\end{array}$ & $\begin{array}{c}782.55 \\
(1256.51)\end{array}$ & $\begin{array}{c}789.65 \\
(1265.21)\end{array}$ & $\begin{array}{c}739.36 \\
(1201.88)\end{array}$ & $\begin{array}{l}-50.29 \\
{[-1.25]}\end{array}$ \\
\hline Value of bank deposits & $\begin{array}{c}264.72 \\
(497.06)\end{array}$ & $\begin{array}{c}351.43 \\
(597.63)\end{array}$ & $\begin{array}{c}355.41 \\
(603.72)\end{array}$ & $\begin{array}{c}327.21 \\
(558.78)\end{array}$ & $\begin{array}{l}-28.20 \\
{[-1.50]}\end{array}$ \\
\hline Positive housing assets & $\begin{array}{c}0.80 \\
(0.40)\end{array}$ & $\begin{array}{c}0.87 \\
(0.34)\end{array}$ & $\begin{array}{c}0.87 \\
(0.34)\end{array}$ & $\begin{array}{c}0.85 \\
(0.35)\end{array}$ & $\begin{array}{l}-0.01 \\
{[-1.13]}\end{array}$ \\
\hline Total value of property & $\begin{array}{c}3660.93 \\
(5963.21)\end{array}$ & $\begin{array}{c}5780.88 \\
(7650.27)\end{array}$ & $\begin{array}{c}5815.97 \\
(7681.69)\end{array}$ & $\begin{array}{c}5567.28 \\
(7456.21)\end{array}$ & $\begin{array}{c}-248.69 \\
{[-1.00]}\end{array}$ \\
\hline Mortgage value & $\begin{array}{c}2508.57 \\
(4333.27)\end{array}$ & $\begin{array}{c}3836.21 \\
(5498.23)\end{array}$ & $\begin{array}{c}3860.45 \\
(5526.72)\end{array}$ & $\begin{array}{c}3688.66 \\
(5321.68)\end{array}$ & $\begin{array}{c}-171.79 \\
{[-0.96]}\end{array}$ \\
\hline Mortgage loan to value & $\begin{array}{c}0.76 \\
(1.09)\end{array}$ & $\begin{array}{c}0.73 \\
(1.00)\end{array}$ & $\begin{array}{c}0.73 \\
(1.01)\end{array}$ & $\begin{array}{c}0.75 \\
(0.92)\end{array}$ & $\begin{array}{c}0.02 \\
{[0.67]}\end{array}$ \\
\hline Total value of debt & $\begin{array}{c}3768.10 \\
(5712.43)\end{array}$ & $\begin{array}{c}5588.72 \\
(7241.19)\end{array}$ & $\begin{array}{c}5612.06 \\
(7266.15)\end{array}$ & $\begin{array}{c}5446.61 \\
(7089.06)\end{array}$ & $\begin{array}{c}-165.44 \\
{[-0.70]}\end{array}$ \\
\hline Bank loans & $\begin{array}{c}1134.51 \\
(1681.26)\end{array}$ & $\begin{array}{c}1557.84 \\
(2103.63)\end{array}$ & $\begin{array}{c}1563.52 \\
(2105.08)\end{array}$ & $\begin{array}{c}1523.27 \\
(2095.44)\end{array}$ & $\begin{array}{l}-40.25 \\
{[-0.58]}\end{array}$ \\
\hline Value of stocks & $\begin{array}{c}191.12 \\
(3067.54)\end{array}$ & $\begin{array}{c}564.80 \\
(5904.89)\end{array}$ & $\begin{array}{c}533.07 \\
(5935.52)\end{array}$ & $\begin{array}{c}757.98 \\
(5713.88)\end{array}$ & $\begin{array}{l}224.91 \\
{[1.18]}\end{array}$ \\
\hline Risk share & $\begin{array}{c}0.15 \\
(0.29)\end{array}$ & $\begin{array}{c}0.43 \\
(0.35)\end{array}$ & $\begin{array}{c}0.43 \\
(0.35)\end{array}$ & $\begin{array}{c}0.45 \\
(0.35)\end{array}$ & $\begin{array}{l}0.02^{*} \\
{[1.86]}\end{array}$ \\
\hline Unique stocks in portfolio & $\begin{array}{c}0.94 \\
(2.42)\end{array}$ & $\begin{array}{c}2.59 \\
(3.75)\end{array}$ & $\begin{array}{c}2.59 \\
(3.75)\end{array}$ & $\begin{array}{c}2.59 \\
(3.78)\end{array}$ & $\begin{array}{c}0.00 \\
{[0.01]}\end{array}$ \\
\hline Observations & 30,082 & 7,449 & 6,398 & 1,051 & - \\
\hline
\end{tabular}


Table 4: Determinants of Entrepreneurship and Bank Choice

The following table presents cross-sectional odds ratios of determinants of entrepreneurship in the year 2006. The dependent variable takes the value of one if the individual is an entrepreneur and zero if otherwise. Bank that later defaults is an indicator variable taking the value of one if the individual has a retail bank account at one of the banks that goes on to later default from 2008-2012. Bank investment default takes the value of one if an individual holds equity investments in a bank which goes on to default during the financial crisis. Mass primary bank indicates whether or not the individual has one of the top-five largest Danish retail banks. Small primary bank indicates whether or not the individual has one a bank with number of customers in the bottom 25 percent of the distribution, while Co-op primary bank indicates whether or not the individual has one of six Danish cooperative retail banks. Columns 1-4 include the full sample while in Columns $5 \& 6$ the sample includes bank investors. In estimations where noted I control for age, age ${ }^{2}$, male, marriage status, education length in years, log wealth, log income, indicator variables for financial education, stock market participation, holding a positive loan balance, receiving unemployment benefits, holding positive housing wealth balance (in either debt or equity), and if the individual is an immigrant. In these specifications, I also control for the year that the firm was established. Industry controls are based on the 2-digit NACE classification in 2006 . Coefficients are the odds ratio after a logistic regression. $*^{* *}, * *$, and $*$ indicate significant at the 1,5 , and 10 percent levels, respectively. Robust standard errors are in parenthesis.

\begin{tabular}{|c|c|c|c|c|c|c|}
\hline & \multicolumn{4}{|c|}{ Full sample } & \multicolumn{2}{|c|}{ Bank investors } \\
\hline & $(1)$ & $(2)$ & $(3)$ & $(4)$ & $(5)$ & $(6)$ \\
\hline Bank that later defaults & $\begin{array}{c}1.0389 \\
(0.0559)\end{array}$ & $\begin{array}{c}0.9671 \\
(0.0447)\end{array}$ & $\begin{array}{c}0.9486 \\
(0.0430)\end{array}$ & $\begin{array}{c}0.9528 \\
(0.0431)\end{array}$ & & \\
\hline Mass primary bank & & $\begin{array}{l}0.8205^{* * *} \\
(0.0159)\end{array}$ & $\begin{array}{l}0.8523^{* * *} \\
(0.0246)\end{array}$ & $\begin{array}{l}0.8522^{* * *} \\
(0.0246)\end{array}$ & & $\begin{array}{l}0.8171^{* * *} \\
(0.0335)\end{array}$ \\
\hline Small primary bank & & & $\begin{array}{l}1.0591^{*} \\
(0.0333)\end{array}$ & $\begin{array}{c}1.0541 \\
(0.0339)\end{array}$ & & $\begin{array}{c}0.9369 \\
(0.0417)\end{array}$ \\
\hline Co-operative bank & & & & $\begin{array}{l}1.0503 \\
(0.0380)\end{array}$ & & $\begin{array}{c}0.9619 \\
(0.1575)\end{array}$ \\
\hline Bank investment default & & & & & $\begin{array}{c}1.0181 \\
(0.0502)\end{array}$ & $\begin{array}{c}0.9918 \\
(0.0557)\end{array}$ \\
\hline Control variables & No & Yes & Yes & Yes & No & Yes \\
\hline Industry fixed effects & Yes & Yes & Yes & Yes & Yes & Yes \\
\hline$R^{2}$ & 0.1485 & 0.2281 & 0.2282 & 0.2282 & 0.1842 & 0.2876 \\
\hline Observations & $1,642,578$ & $1,642,578$ & $1,642,578$ & $1,642,578$ & 235,387 & 235,387 \\
\hline
\end{tabular}


Table 5: Deposit Customer Bank Separations

The following table reports the unconditional proportion of individuals in the sample who continue with the same primary retail bank from year to year. Each row corresponds to the proportion of individuals who continue to keep their same primary retail bank in the following year. Column 1 focuses on individuals who have a one of the top-five largest Danish retail banks in 2005. Column 2 includes all individuals with primary retail banks outside of the top-five largest and retail banks which default throughout the financial crisis. Column 3 focuses on only individuals with primary retail banks which go on to default from 2008-2012. Panel A presents the year-to-year unconditional probability while Panel B presents the cumulative proportion of individuals continuing with their 2005 bank.

Panel A: Year-to-year

\begin{tabular}{|c|c|c|c|}
\hline \multirow[b]{2}{*}{ Continue with same bank (\%) } & \multicolumn{3}{|c|}{ Type of customer } \\
\hline & $\begin{array}{c}\text { Large bank } \\
(1)\end{array}$ & $\begin{array}{c}\text { Local bank } \\
(2)\end{array}$ & $\begin{array}{c}\text { Default bank } \\
(3)\end{array}$ \\
\hline $2005-2006$ & 89.82 & 89.76 & 90.23 \\
\hline 2006-2007 & 93.02 & 92.82 & 94.29 \\
\hline $2007-2008$ & 93.69 & 94.18 & 90.49 \\
\hline 2008-2009 & 90.61 & 94.19 & 67.48 \\
\hline 2009-2010 & 94.39 & 95.26 & 88.81 \\
\hline 2010-2011 & 93.61 & 94.58 & 87.37 \\
\hline 2011-2012 & 92.29 & 94.95 & 75.10 \\
\hline
\end{tabular}

Panel B: Cumulative

\begin{tabular}{|c|c|c|c|}
\hline \multirow[b]{2}{*}{ Continue with same bank (\%) } & \multicolumn{3}{|c|}{ Type of customer } \\
\hline & $\begin{array}{c}\text { Large bank } \\
\text { (1) }\end{array}$ & $\begin{array}{c}\text { Local bank } \\
\text { (2) }\end{array}$ & $\begin{array}{c}\text { Default bank } \\
\text { (3) }\end{array}$ \\
\hline $2005-2005$ & 100.00 & 100.00 & 100.00 \\
\hline 2005-2006 & 89.82 & 89.76 & 90.23 \\
\hline 2005-2007 & 83.80 & 83.57 & 85.32 \\
\hline 2005-2008 & 78.93 & 79.14 & 77.58 \\
\hline 2005-2009 & 71.90 & 75.32 & 49.86 \\
\hline 2005-2010 & 68.49 & 72.48 & 42.69 \\
\hline 2005-2011 & 64.70 & 69.32 & 34.82 \\
\hline 2005-2012 & 59.63 & 66.58 & 14.71 \\
\hline
\end{tabular}


Table 6: Personal Financing Disruptions and Channels of Financing

The following table analyzes the effect of a exposure to bank defaults on bank lending and liquid wealth holdings. In Columns 1-2 \& 5-6 the dependent variable is the total amount of bank loans in 1,000 DKK held by an entrepreneur at the end of the year, while in Columns $3-4 \& 7-8$ the dependent variable is the log of the market value, year-end sum of liquid wealth. Liquid wealth includes bank deposits, stock assets, and investment bond assets. The variable exposed depositor indicates whether the entrepreneur had a retail bank which defaulted in the years after the financial crisis. The variable takes the value of one in all post-default years. Similarly, the variable exposed investor indicates whether the entrepreneur held equity investments in a retail bank which defaulted in the years after the financial crisis, again the variable takes the value of one in post-default years. In Columns 1-4 the sample includes all individuals who were entrepreneurs at least for one year prior to 2007 and excludes investment account holders, i.e., the sample of bank depositors. In Columns 5-8 the sample includes all individuals who were entrepreneurs at least for one year prior to 2007 and held retail bank investments between 2005-2007, i.e., bank investors. In all specifications I control for calendar year fixed effects. In Columns 1, 3, 5, \& 7 the specifications also include bank-cohort controls, and demographic controls including the following: age, age $e^{2}$, male, marriage status, education length in years, log wealth, log income, and child in household, financial education, stock market participation, holding a positive loan balance, receiving unemployment benefits, holding positive housing wealth balance (in either debt or equity), and if the individual is an immigrant. In these specifications, I also control for the year that the firm was established. In Columns 2, 4, 6 \& 8 the specifications include individual-entrepreneur fixed effects and the following time-varying demographic controls: log wealth, log income, and if the entrepreneur has a child or purchases a house at time $t$. Regression coefficients are estimated with OLS. ***, **, and * indicate significant at the 1,5 , and 10 percent levels, respectively. Robust standard errors clustered at the pre-crisis primary bank level are in parenthesis.

\begin{tabular}{|c|c|c|c|c|c|c|c|c|}
\hline & \multicolumn{4}{|c|}{ Bank depositors } & \multicolumn{4}{|c|}{ Bank investors } \\
\hline & \multicolumn{2}{|c|}{ Bank loans (1000 DKK) } & \multicolumn{2}{|c|}{ Log (liquid wealth) } & \multicolumn{2}{|c|}{ Bank loans (1000 DKK) } & \multicolumn{2}{|c|}{ Log (liquid wealth) } \\
\hline & $(1)$ & $(2)$ & $(3)$ & $(4)$ & $(5)$ & $(6)$ & $(7)$ & $(8)$ \\
\hline Exposed depositor & $\begin{array}{l}-208.2543^{* *} \\
(92.4209)\end{array}$ & $\begin{array}{l}-70.6171^{* *} \\
(30.7461)\end{array}$ & $\begin{array}{l}-0.1232 \\
(0.0749)\end{array}$ & $\begin{array}{l}-0.1036 \\
(0.0871)\end{array}$ & & & & \\
\hline Exposed investor & & & & & $\begin{array}{c}41.3860 \\
(121.8386)\end{array}$ & $\begin{array}{l}-10.6130 \\
(64.7234)\end{array}$ & $\begin{array}{l}-0.3504^{* * *} \\
(0.0860)\end{array}$ & $\begin{array}{l}-0.3200^{* * *} \\
(0.0683)\end{array}$ \\
\hline Control variables & Yes & Yes & Yes & Yes & Yes & Yes & Yes & Yes \\
\hline Year fixed effects & Yes & Yes & Yes & Yes & Yes & Yes & Yes & Yes \\
\hline $\begin{array}{l}\text { Individual fixed } \\
\text { effects }\end{array}$ & No & Yes & No & Yes & No & Yes & No & Yes \\
\hline$R^{2}$ & 0.1021 & 0.6954 & 0.1079 & 0.4967 & 0.0845 & 0.6979 & 0.1560 & 0.5750 \\
\hline Observations & 351,170 & 351,170 & 351,170 & 351,170 & 97,950 & 97,950 & 97,950 & 97,950 \\
\hline
\end{tabular}


Table 7: Firm Exit and Access to Debt Financing

The following table analyzes the effect of a change in individual access to bank credit availability on the propensity to exit entrepreneurship. The dependent variable is an indicator variable for exiting entrepreneurship, conditional on being an entrepreneur in the last period. The variable exposure to default bank indicates whether the entrepreneur has a primary retail bank which goes on to default during the financial crisis. The variable takes the value of one if year $t$ is after the year of default and zero if otherwise. The variable exposure to bank merger indicates whether the entrepreneur has a primary retail bank which rather than default, was included in an independent merger and/or acquisition with another retail bank. The variable takes the value of one in postmerger years. In Columns 1-4 the sample includes all entrepreneurs while Columns 5-8 feature a sub-sample which discards entrepreneurs who hold stock investment accounts. In all specifications I control for calendar year effects. In Columns 1-3 \& 5-7 the specifications also include bank-cohort controls, and demographic controls including the following: age, age ${ }^{2}$, male, marriage status, education length in years, log wealth, log income, and child in household, financial education, stock market participation, holding a positive loan balance, receiving unemployment benefits, holding positive housing wealth balance (in either debt or equity), and if the individual is an immigrant. In these specifications, I also control for the year that the firm was established. In Columns 4 \& 8 the specifications include individual-entrepreneur fixed effects and the following time-varying demographic controls: log wealth, log income, and if the entrepreneur has a child or purchases a house at time $t$. Regression coefficients are estimated with OLS. ***, **, and * indicate significant at the 1,5 , and 10 percent levels, respectively. Robust standard errors clustered at the pre-crisis primary bank level are in parenthesis.

Full sample

\begin{tabular}{lc}
$\operatorname{Pr}($ exit $)$ & $(1)$ \\
\hline Exposure to default bank & $0.0160^{*}$ \\
$(0.0087)$
\end{tabular}

\section{Full sample}

Exposure to bank merger

$(2)$

\section{le}

$1 * * \quad 0.02$

(4)

$0.0250^{* * *}$
$(0.0084)$
0.0001

$\begin{array}{ccc}0.0043 & 0.0068 & 0.0001 \\ (0.0067) & (0.0068) & (0.0127)\end{array}$

(0.0127)



\begin{tabular}{|c|c|c|c|c|c|c|c|c|}
\hline Control variables & Yes & Yes & Yes & Yes & Yes & Yes & Yes & Yes \\
\hline Year fixed effects & Yes & Yes & Yes & Yes & Yes & Yes & Yes & Yes \\
\hline Individual fixed effects & No & No & No & Yes & No & No & No & Yes \\
\hline$R^{2}$ & 0.0477 & 0.0477 & 0.0477 & 0.2912 & 0.0482 & 0.0482 & 0.0482 & 0.2915 \\
\hline Observations & 276,692 & 276,692 & 276,692 & 276,692 & 261,680 & 261,680 & 261,680 & 261,680 \\
\hline
\end{tabular}


Table 8: Firm Exit, Access to Debt Financing, and Local Market Demand

The following table analyzes the effect of a change in individual access to bank credit availability on the propensity to exit entrepreneurship. The dependent variable is an indicator variable for exiting entrepreneurship, conditional on being an entrepreneur in the last period. The variable exposure to default bank indicates whether the entrepreneur has a primary retail bank which goes on to default during the financial crisis. The variable takes the value of one if year $t$ is after the year of default and zero if otherwise. The variable exposure to bank merger indicates whether the entrepreneur has a primary retail bank which rather than default, was included in an independent merger and/or acquisition with another retail bank. The variable takes the value of one in post-merger years. In Columns 1-3 the sample includes all entrepreneurs while Columns 4-6 feature a sub-sample which discards entrepreneurs who hold stock investment accounts. Columns 1 \& 4 contain a sample where exposed entrepreneur depositors are matched with unexposed entrepreneurs in the same municipality, Columns $2 \& 5$ match exposed entrepreneurs to unexposed entrepreneurs in the same parish. Matching is based on 5 nearest neighbor exact matching on municipality or parish, five-year age cohort, pre-crisis wealth, gender, and marital status. Columns $3 \& 5$ focuses on an exclusive subsample of entrepreneurs whose firm is located in a municipality outside of the municipality in which they live in. In all specifications I control for calendar year effects and individual-entrepreneur fixed effects and the following time-varying demographic controls: log wealth, log income, and if the entrepreneur has a child or purchases a house at time $t$. Regression coefficients are estimated with OLS. ***, **, and * indicate significant at the 1,5 , and 10 percent levels, respectively. Robust standard errors clustered at the pre-crisis primary bank level are in parenthesis.

\begin{tabular}{|c|c|c|c|c|c|c|}
\hline \multirow[b]{3}{*}{$\operatorname{Pr}($ exit $)$} & \multicolumn{3}{|c|}{ Full sample } & \multicolumn{3}{|c|}{ Bank depositors } \\
\hline & Municipality & Parish & Outside & Municipality & Parish & Outside \\
\hline & $(1)$ & $(2)$ & $(3)$ & $(4)$ & $(5)$ & $(6)$ \\
\hline \multirow[t]{2}{*}{ Exposure to default bank } & $0.0209^{* *}$ & $0.0221^{* *}$ & $0.0468^{* * *}$ & $0.0195^{*}$ & $0.0206^{*}$ & $0.0510^{* *}$ \\
\hline & $(0.0100)$ & $(0.0099)$ & $(0.0173)$ & $(0.0108)$ & $(0.0124)$ & $(0.0225)$ \\
\hline \multirow{2}{*}{ Exposed to bank merger } & 0.0024 & -0.0106 & $-0.0507 * *$ & -0.0031 & -0.0154 & $-0.0515^{* *}$ \\
\hline & $(0.0226)$ & $(0.0179)$ & $(0.0234)$ & $(0.0188)$ & $(0.0199)$ & $(0.0239)$ \\
\hline Control variables & Yes & Yes & Yes & Yes & Yes & Yes \\
\hline Year fixed effects & Yes & Yes & Yes & Yes & Yes & Yes \\
\hline Individual fixed effects & Yes & Yes & Yes & Yes & Yes & Yes \\
\hline$R^{2}$ & 0.2909 & 0.2907 & 0.3291 & 0.2897 & 0.2902 & 0.3286 \\
\hline Observations & 66,023 & 59,168 & 49,215 & 56,944 & 50,465 & 46,946 \\
\hline
\end{tabular}


Table 9: Firm Exit and Changes in Personal Wealth

The following table analyzes the effect of a change in personal liquid wealth on the propensity to exit entrepreneurship stemming from Equation (2). The dependent variable is an indicator variable for exiting entrepreneurship, conditional on being an entrepreneur in the last period. The variable personal wealth losses indicates whether the entrepreneur held stock investments in a default bank and incurred above median financial losses. The variable takes the value of one if year $t$ is after the bank default year and zero if otherwise. In Columns 1 \& 2 the sample includes all entrepreneurs who invest in retail bank stocks, while in Columns $3 \& 4$ entrepreneurs who incurred financial losses by investing in their own deposit bank are excluded. In Columns 5 \& 6 the sample contains entrepreneurs who either lost access to their retail bank, or lost liquidity due to wealth losses from default bank investments. In all specifications I control for year time effects. In Columns $1,3, \& 5$ the specifications also include default year-cohort controls, and demographic controls including the following: age, age ${ }^{2}$, male, marriage status, education length in years, log wealth, log income, and child in household, financial education, stock market participation, holding a positive loan balance, receiving unemployment benefits, holding positive housing wealth balance (in either debt or equity), and if the individual is an immigrant. In these specifications, I also control for the year that the firm was established. In Columns $2,4 \& 6$ the specifications include individual-entrepreneur fixed effects and the following time-varying demographic controls: $\log$ wealth, log income, and if the entrepreneur has a child or purchases a house at time $t$. Regression coefficients are estimated with OLS. ***, **, and * indicate significant at the 1,5 , and 10 percent levels, respectively. Robust standard errors clustered at the pre-crisis primary bank level are in parenthesis.

\begin{tabular}{|c|c|c|c|c|c|c|}
\hline \multirow[b]{3}{*}{$\operatorname{Pr}($ exit $)$} & \multicolumn{6}{|c|}{ All entrepreneurs } \\
\hline & \multicolumn{2}{|c|}{ Bank investors } & \multicolumn{2}{|c|}{ Depositors excluded } & \multicolumn{2}{|c|}{ Access to credit } \\
\hline & (1) & $(2)$ & $(3)$ & $(4)$ & $(5)$ & (6) \\
\hline Personal wealth losses & $\begin{array}{l}0.0543^{* * *} \\
(0.0102)\end{array}$ & $\begin{array}{l}0.0583^{* * *} \\
(0.0137)\end{array}$ & $\begin{array}{l}0.0637^{* * *} \\
(0.0101)\end{array}$ & $\begin{array}{l}0.0603^{* * *} \\
(0.0081)\end{array}$ & $\begin{array}{l}0.0657^{* * *} \\
(0.0124)\end{array}$ & $\begin{array}{l}0.0586^{* * *} \\
(0.0123)\end{array}$ \\
\hline Control variables & Yes & Yes & Yes & Yes & Yes & Yes \\
\hline Year fixed effects & Yes & Yes & Yes & Yes & Yes & Yes \\
\hline Individual fixed effects & No & Yes & No & Yes & No & Yes \\
\hline$R^{2}$ & 0.0357 & 0.2800 & 0.0347 & 0.2795 & 0.0389 & 0.2745 \\
\hline Observations & 69,114 & 69,114 & 62,785 & 62,785 & 11,732 & 11,732 \\
\hline
\end{tabular}


Table 10: Firm Exit, Changes in Personal Wealth, and Heterogeneity in Experience

The following table analyzes the effect of a change in individual liquid wealth on the propensity to exit entrepreneurship stemming from Equation (2). The dependent variable is an indicator variable for exiting entrepreneurship, conditional on being an entrepreneur in the last period. The variable personal wealth losses indicates whether the entrepreneur held stock investments in a default bank and incurred above median financial losses. The variable takes the value of one if year $t$ is after the bank default year and zero if otherwise. Columns 1-3 focus on the a sample of established entrepreneurs. Established entrepreneurs began their firm at any time prior to 2002, while in Columns 4-6 the sample consists of new entrepreneurs who started their first venture in the years prior to the financial crisis, 2002-2007. In Columns $1 \& 4$ the sample includes all entrepreneurs who invest in retail bank stocks, while in Columns $2 \& 5$ entrepreneurs who incurred financial losses by investing in their own deposit bank are excluded. In Columns 3 \& 6 the sample contains entrepreneurs who either lost access to their retail bank, or lost liquidity due to wealth losses from default bank investments. In all specifications I control for year time effects. All specifications include individual-entrepreneur fixed effects and the following time-varying demographic controls: log wealth, log income, and if the entrepreneur has a child or purchases a house at time $t$. Regression coefficients are estimated with OLS. ***, **, and * indicate significant at the 1,5 , and 10 percent levels, respectively. Robust standard errors clustered at the pre-crisis primary bank level are in parenthesis.

\begin{tabular}{|c|c|c|c|c|c|c|}
\hline \multirow[b]{2}{*}{$\underline{\operatorname{Pr}(\text { exit })}$} & \multicolumn{3}{|c|}{ Established entrepreneurs } & \multicolumn{3}{|c|}{ New entrepreneurs } \\
\hline & $\begin{array}{c}\text { Bank investors } \\
\text { (1) }\end{array}$ & $\begin{array}{c}\text { Depositors excluded } \\
(2)\end{array}$ & $\begin{array}{c}\text { Access to credit } \\
(3)\end{array}$ & $\begin{array}{c}\text { Bank investors } \\
\text { (4) }\end{array}$ & $\begin{array}{c}\text { Depositors excluded } \\
(5)\end{array}$ & $\begin{array}{c}\text { Access to credit } \\
\text { (6) }\end{array}$ \\
\hline Personal wealth losses & $\begin{array}{l}0.0489^{* * *} \\
(0.0117)\end{array}$ & $\begin{array}{l}0.0563^{* * *} \\
(0.0209)\end{array}$ & $\begin{array}{l}0.0446^{* * *} \\
(0.0139)\end{array}$ & $\begin{array}{l}0.0981^{* * *} \\
(0.0362)\end{array}$ & $\begin{array}{l}0.1294^{* *} \\
(0.0580)\end{array}$ & $\begin{array}{l}0.1552^{* * *} \\
(0.0519)\end{array}$ \\
\hline Control variables & Yes & Yes & Yes & Yes & Yes & Yes \\
\hline Year fixed effects & Yes & Yes & Yes & Yes & Yes & Yes \\
\hline Individual fixed effects & Yes & Yes & Yes & Yes & Yes & Yes \\
\hline$R^{2}$ & 0.2527 & 0.2559 & 0.2366 & 0.2639 & 0.2581 & 0.2744 \\
\hline Observations & 38,013 & 34,671 & 6,361 & 19,400 & 17,394 & 3,548 \\
\hline
\end{tabular}


The following table analyzes the the effect of exposure to bank defaults on firm exit as shown in the hazard specification of Equation 6 . The dependent variable is the baseline hazard $\lambda_{i, 0}(\tau)$ of firm exit after $\tau$ years. The variable exposure to default bank indicates whether the entrepreneur has a primary retail bank which goes on to default during the financial crisis. The variable takes the value of one if calendar year $t$ is after 2008 and zero if otherwise. The variable exposure to bank merger indicates whether the entrepreneur has a primary retail bank which rather than default, was included in an independent merger and/or acquisition with another retail bank. The variable takes the value of one in post-merger years. The variable personal wealth losses indicates whether the entrepreneur held stock investments in a default bank. The variable takes the value of one in post-default years. In Columns 1-5 the sample includes bank depositors. Columns 4 \& 5 further restrict the sample to bank depositors who do not hold investment accounts. Columns $6-8$ focus on a sample of bank-investor entrepreneurs. In Column 8 I discard investors who hold deposit accounts in banks which default. Columns 5 \& 8 restrict the sample to entrepreneurs who started their firm after 1990 in order to account for left-censoring of a number of observations. All specifications also include default year-cohort controls, and demographic controls including the following: age, age ${ }^{2}$, male, marriage status, education length in years, log wealth, log income, and child in household, financial education, stock market participation, holding a positive loan balance, receiving unemployment benefits, holding positive housing wealth balance (in either debt or equity), and if the individual is an immigrant. Regression coefficients are estimated with a Cox proportional hazard model and shown in hazard ratios. ${ }^{* *},{ }^{* *}$, and ${ }^{*}$ indicate significant at the 1,5 , and 10 percent levels, respectively. Robust standard errors clustered at the pre-crisis primary bank level are in parenthesis.

\begin{tabular}{|c|c|c|c|c|c|c|c|c|}
\hline \multirow[b]{3}{*}{$\overline{\operatorname{Pr}(\text { exit })}$} & \multicolumn{5}{|c|}{ Bank depositors } & \multicolumn{3}{|c|}{ Bank investors } \\
\hline & \multicolumn{3}{|c|}{ Full Sample } & \multicolumn{2}{|c|}{ Depositors Only } & \multirow{2}{*}{$\frac{\text { Full Sample }}{(6)}$} & \multicolumn{2}{|c|}{ Excluding Depositors } \\
\hline & $(1)$ & $(2)$ & $(3)$ & $(4)$ & $(5)$ & & $(7)$ & $(8)$ \\
\hline Exposure to bank default & $\begin{array}{l}1.1164^{* * *} \\
(0.0489)\end{array}$ & & $\begin{array}{l}1.1171^{* * *} \\
(0.0490)\end{array}$ & $\begin{array}{c}1.0895^{*} \\
(0.0501)\end{array}$ & $\begin{array}{c}1.1009 * \\
(0.0535)\end{array}$ & & & \\
\hline Exposure to bank merger & & $\begin{array}{l}1.0002 \\
(0.0641)\end{array}$ & $\begin{array}{l}1.0047 \\
(0.0636)\end{array}$ & $\begin{array}{l}0.9735 \\
(0.0604)\end{array}$ & $\begin{array}{c}0.9753 \\
(0.0561)\end{array}$ & & & \\
\hline Personal wealth losses & & & & & & $\begin{array}{l}1.2916^{* * *} \\
(0.0828)\end{array}$ & $\begin{array}{l}1.3168^{* * *} \\
(0.1253)\end{array}$ & $\begin{array}{l}1.4700^{\text {*** }} \\
(0.1353)\end{array}$ \\
\hline Left censoring & No & No & No & No & Yes & No & No & Yes \\
\hline Control variables & Yes & Yes & Yes & Yes & Yes & Yes & Yes & Yes \\
\hline Municipality dummies & Yes & Yes & Yes & Yes & Yes & Yes & Yes & Yes \\
\hline Observations & 231,971 & 231,971 & 231,971 & 219,343 & 188,252 & 50,118 & 45,471 & 36,800 \\
\hline
\end{tabular}


Table 12: Hazard of Firm Exit: Competing Risks

The following table analyzes the the effect of exposure to bank defaults on firm exit as shown in the competing risk specification of Equation 6. The dependent variable is the baseline subhazard $\hat{\lambda}_{i, k, 0}(\tau)$ of firm exit after $\tau$ years which results in exit-outcome $k$. For both panels, in Column 1, entrepreneurs exit their venture and enter into a state of unemployment or exit the labor market completely. In Column 2, entrepreneurs enter into a nonownership, salaried position, at a new firm after exiting from their venture. In Column 3, entrepreneurs remain in the current venture, however either downsize their employees and/or take on a self-employment designation. Finally, in Column 4, entrepreneurs exit their venture to start up a new entrepreneurial firm. Panel A presents the results across the bank depositor sample (excluding depositors who hold investment accounts) and considers the effect of an entrepreneur's primary retail bank defaulting on each one of these outcomes, while taking into consideration the remaining three remaining competing risk outcomes. Panel B focuses on the bank investor sample excluding investors who hold deposit accounts at a bank which defaults. The variable exposure to default bank indicates whether the entrepreneur has a primary retail bank which goes on to default during the financial crisis. The variable takes the value of one if calendar year $t$ is after 2008 and zero if otherwise. The variable $e x-$ posure to bank merger indicates whether the entrepreneur has a primary retail bank which rather than default, was included in an independent merger and/or acquisition with another retail bank. The variable takes the value of one in post-merger years. The variable personal wealth losses indicates whether the entrepreneur held stock investments in a default bank. The variable takes the value of one in post-default years. All specifications also include default year-cohort controls, and demographic controls including the following: age, age ${ }^{2}$, male, marriage status, education length in years, log wealth, log income, and child in household, financial education, stock market participation, holding a positive loan balance, receiving unemployment benefits, holding positive housing wealth balance (in either debt or equity), and if the individual is an immigrant. Regression coefficients are estimated with a Fine and Gray proportional competing risk hazard model and shown in subhazard ratios. ***, **, and * indicate significant at the 1, 5, and 10 percent levels, respectively. Robust standard errors clustered at the pre-crisis primary bank level are in parenthesis.

Panel A:

\begin{tabular}{lcccc}
\hline \hline & & \multicolumn{2}{c}{ Bank depositors } & \\
& Unemployment & Labor market & Self-employment & New start-up \\
& $(1)$ & $(2)$ & $(3)$ & $(4)$ \\
\hline Exposure to bank default & $1.3748^{*}$ & 1.0563 & 0.9901 & 0.9179 \\
& $(0.1796)$ & $(0.0926)$ & $(0.1271)$ & $(0.1007)$ \\
Exposure to bank merger & 1.1454 & 0.9596 & 0.9619 & 1.097 \\
& $(0.1490)$ & $(0.7916)$ & $(0.0644)$ & $(0.0989)$ \\
Control variables & & & & Yes \\
\hline Observations & Yes & Yes & 100,884 & 109,045 \\
\hline \hline
\end{tabular}

Panel B:

Bank investors

Unemployment Labor market Self-employment New start-up

(1)

(2)

(3)

(4)

Personal wealth losses $\quad 0.8351$

$1.8093^{* * *} \quad 1.6483^{*}$

0.8633

(0.2281)

(0.2177)

$(0.2928)$

$(0.1233)$

\begin{tabular}{lcccc} 
Control variables & Yes & Yes & Yes & Yes \\
\hline Observations & 51,381 & 51,481 & 47,110 & 50,459 \\
\hline \hline
\end{tabular}


Table 13: Personal Financing Disruptions and Employment Decisions

The following table analyzes the effects of exposure to bank defaults and changes in personal liquid wealth on the change in employees employed by an entrepreneur. The dependent variable is the number of employees, conditional on being an entrepreneur at time $t$. The variable exposure to bank default indicates whether an entrepreneur has a personal retail bank which defaults during the financial crisis. The variable takes the value of one in postdefault years. The variable personal wealth losses indicates whether the entrepreneur held stock investments in a default bank and incurred above median financial losses. The variable takes the value of one if year $t$ is after the bank default year and zero if otherwise. In Columns $1 \& 2$ the sample includes all entrepreneurs who have a retail bank, in Column 2 I exclude entrepreneurs who also hold equity investments. In Columns $3 \& 4$ the sample focuses on entrepreneurs who hold investments in retail bank equities. Column 4 excludes entrepreneurs who also have a retail bank which defaults. All specifications control for calendar year fixed effects and individualentrepreneur fixed effects and the following time-varying demographic controls: log wealth, log income, and if the entrepreneur has a child or purchases a house at time $t$. Regression coefficients are estimated with OLS. ***, **, and ${ }^{*}$ indicate significant at the 1,5 , and 10 percent levels, respectively. Robust standard errors are clustered at the entrepreneur's 2-digit industry classification and shown in parenthesis.

\begin{tabular}{lcccc}
\hline \hline & \multicolumn{2}{c}{ Bank depositors } & \multicolumn{2}{c}{ Bank investors } \\
Number of employees & $(1)$ & $(2)$ & $(3)$ & $(4)$ \\
\hline Exposure to bank default & -0.1031 & -0.1395 & & \\
Personal wealth losses & $(0.0963)$ & $(0.0871)$ & & $-0.2611^{* *}$ \\
& & & $(0.1285)$ & $-0.7246^{* * *}$ \\
& & & $0.2427)$ \\
Control variables & Yes & Yes & Yes & Yes \\
Year fixed effects & Yes & Yes & Yes & Yes \\
Individual fixed effects & Yes & Yes & Yes & Yes \\
$R^{2}$ & 0.7698 & 0.7690 & 0.7993 & 0.8009 \\
\hline Observations & 284,698 & 269,231 & 70,779 & 64,323 \\
\hline \hline
\end{tabular}


Table 14: Firm Exit, Personal Financing Disruptions, and Household Heterogeneity

The following table analyzes the effects exposure to bank defaults and changes in personal liquid wealth on the propensity to exit entrepreneurship stemming from Equation (2). The dependent variable is an indicator variable for exiting entrepreneurship, conditional on being an entrepreneur in the last period. The variable exposure to bank default indicates whether an entrepreneur has a personal retail bank which defaults during the financial crisis. The variable takes the value of one in post-default years. The variable personal wealth losses indicates whether the entrepreneur held stock investments in a default bank and incurred above median financial losses. The variable takes the value of one if year $t$ is after the bank default year and zero if otherwise. Columns $1 \& 2$ focuses on the depositor sample of entrepreneurs while Columns $3 \& 4$ focus on the investor sample. In Columns $1 \& 3$ the sample consists of married entrepreneurs whose income share to the total household is less than 50 percent. In Columns $2 \& 4$ married entrepreneurs income share within the household is greater than or equal to 50 percent. All specifications control for calendar year fixed effects and individual-entrepreneur fixed effects and the following time-varying demographic controls: log wealth, log income, and if the entrepreneur has a child or purchases a house at time $t$. Regression coefficients are estimated with OLS. ${ }^{* * *}{ }^{* *}$, and $*$ indicate significant at the 1, 5, and 10 percent levels, respectively. Robust standard errors are clustered at the entrepreneur's 2-digit industry classification and shown in parenthesis.

\begin{tabular}{lcccc}
\hline \hline \multirow{2}{*}{ Income share } & \multicolumn{2}{c}{ Bank depositors } & \multicolumn{2}{c}{ Bank investors } \\
& Low & High & Low & High \\
& $(1)$ & $(2)$ & $(3)$ & $(4)$ \\
\hline Exposure to bank default & 0.0283 & 0.0034 & & \\
Personal wealth losses & $(0.0223)$ & $(0.0158)$ & & \\
& & & 0.0146 & $0.0653^{* * *}$ \\
Control variables & & & $(0.0553)$ & $(0.0110)$ \\
Year fixed effects & Yes & Yes & Yes & Yes \\
Individual fixed effects & Yes & Yes & Yes & Yes \\
$R^{2}$ & Yes & Yes & Yes & Yes \\
\hline Observations & 0.2948 & 0.2844 & 0.2834 & 0.2739 \\
\hline \hline
\end{tabular}


Table 15: Firm Exit, Personal Financing Disruptions, and Heterogeneity in Wealth and Debt

The following table analyzes the effects exposure to bank defaults and changes in personal liquid wealth on the propensity to exit entrepreneurship stemming from Equation (2). The dependent variable is an indicator variable for exiting entrepreneurship, conditional on being an entrepreneur in the last period. The variable exposure to bank default indicates whether an entrepreneur has a personal retail bank which defaults during the financial crisis. The variable takes the value of one in post-default years. The variable personal wealth losses indicates whether the entrepreneur held stock investments in a default bank and incurred above median financial losses. The variable takes the value of one if year $t$ is after the bank default year and zero if otherwise. In Columns 1-3 the sample includes all entrepreneurs who have a retail bank excluding entrepreneurs who also hold equity investments. In Columns 4-6 the sample focuses on entrepreneurs who hold investments in retail bank equities excluding entrepreneurs who also have a retail bank which defaults. The sample is divided into terciles such that Column 1 (2) (3) includes the bottom (middle) (top) third of the distribution. Panel A separates this for net wealth while Panel B separates total sources of debt. All specifications control for calendar year fixed effects and individual-entrepreneur fixed effects and the following time-varying demographic controls: log wealth, log income, and if the entrepreneur has a child or purchases a house at time $t$. Regression coefficients are estimated with OLS. $* * *, * *$, and $*$ indicate significant at the 1,5 , and 10 percent levels, respectively. Robust standard errors are clustered at the entrepreneur's 2 -digit industry classification and shown in parenthesis.

Panel A: Wealth

\begin{tabular}{lccc} 
& \multicolumn{3}{c}{ Bank depositors } \\
& Bottom & Middle & Top \\
& $(1)$ & $(2)$ & $(3)$ \\
\hline Exposure to bank default & 0.0061 & 0.0411 & -0.0085 \\
& $(0.0227)$ & $(0.0260)$ & $(0.0261)$
\end{tabular}

Personal wealth losses

$(0.0261)$

Person wealth losses

\begin{tabular}{llllll}
$R^{2}$ & 0.2837 & 0.2383 & 0.2544 & 0.2528 & 0.2505 \\
Observations & 80,648 & 75,324 & 77,666 & 19,227 & 19,348 \\
\hline
\end{tabular}

\section{Panel B: Debt}

\begin{tabular}{|c|c|c|c|c|c|c|}
\hline & \multicolumn{3}{|c|}{ Bank depositors } & \multicolumn{3}{|c|}{ Bank investors } \\
\hline & $\begin{array}{c}\text { Bottom } \\
(1)\end{array}$ & $\begin{array}{c}\text { Middle } \\
(2)\end{array}$ & $\begin{array}{c}\text { Top } \\
(3)\end{array}$ & $\begin{array}{c}\text { Bottom } \\
(4)\end{array}$ & $\begin{array}{c}\text { Middle } \\
(5)\end{array}$ & $\begin{array}{c}\text { Top } \\
(6)\end{array}$ \\
\hline Exposure to bank default & $\begin{array}{c}0.0148 \\
(0.0174)\end{array}$ & $\begin{array}{c}0.0026 \\
(0.0234)\end{array}$ & $\begin{array}{c}0.0314 \\
(0.0215)\end{array}$ & & & \\
\hline Personal wealth losses & & & & $\begin{array}{c}0.0382 \\
(0.0354)\end{array}$ & $\begin{array}{c}0.0280 \\
(0.0242)\end{array}$ & $\begin{array}{c}0.0995^{* *} \\
(0.0457)\end{array}$ \\
\hline$R^{2}$ & 0.2798 & 0.2620 & 0.2406 & 0.2752 & 0.2519 & 0.2463 \\
\hline Observations & 76,479 & 78,142 & 79,017 & 19,240 & 19,060 & 20,298 \\
\hline
\end{tabular}




\section{Figure 1: Investment Returns}

The following figure plots an index of market returns for investors in the sample using micro-data on year-end portfolio holdings at the individual asset level. The solid dark line plots of an index of returns for retail bank stocks which go on to default throughout the financial crisis. The dashed line plots the index for bank stocks which remain solvent and do not default during the crisis, the solid gray line plots a portfolio of all other stocks. The portfolio is indexed to year 2006 .

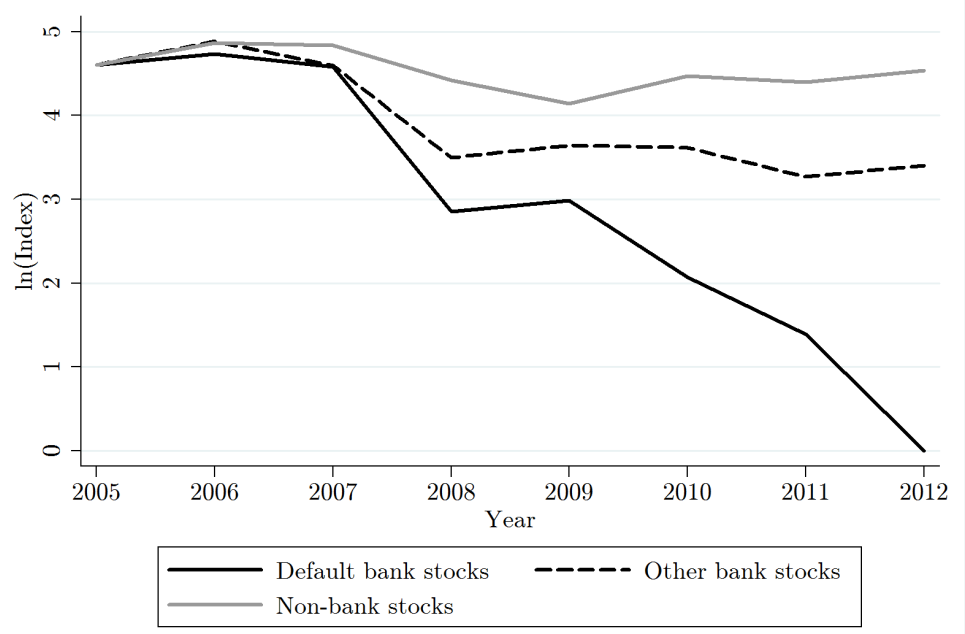

The following figure plots the distribution of monthly returns for Danish retail bank stocks between January $1^{\text {st }}, 2005$ and December $1^{\text {st }}, 2007$. The dashed line plots the the distribution for monthly returns for a market capitalization-weighted portfolio of retail bank stocks which remain solvent following the financial crisis while the solid line plots a portfolio of retail bank stocks which default between 2008-2012. The vertical lines provide the mean return for each distribution. A Kolmogorov-Smirnov test (at right) is performed to test if the two distributions statistically differ.

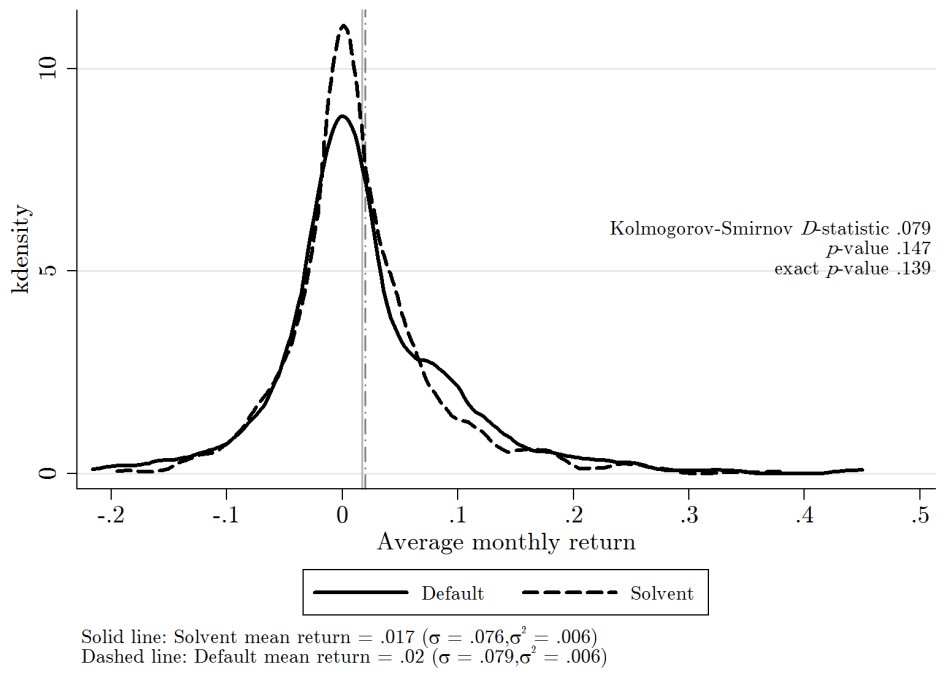


Figure 2: Deposit Customer Bank Separations

The following figure shows the unconditional proportion of individuals in the sample who continue with the same primary retail bank from 2005 to year $t$. Each bar corresponds to the proportion of individuals who continue to keep their same primary retail bank in the current year. The light gray bars focus on individuals who have one of the five largest Danish retail banks in 2005. The darker gray bars include all individuals with primary retail banks outside of the top-five largest and retail banks which default throughout the financial crisis. The black bars focus on only individuals with primary retail banks which go on to default from 2008-2012.

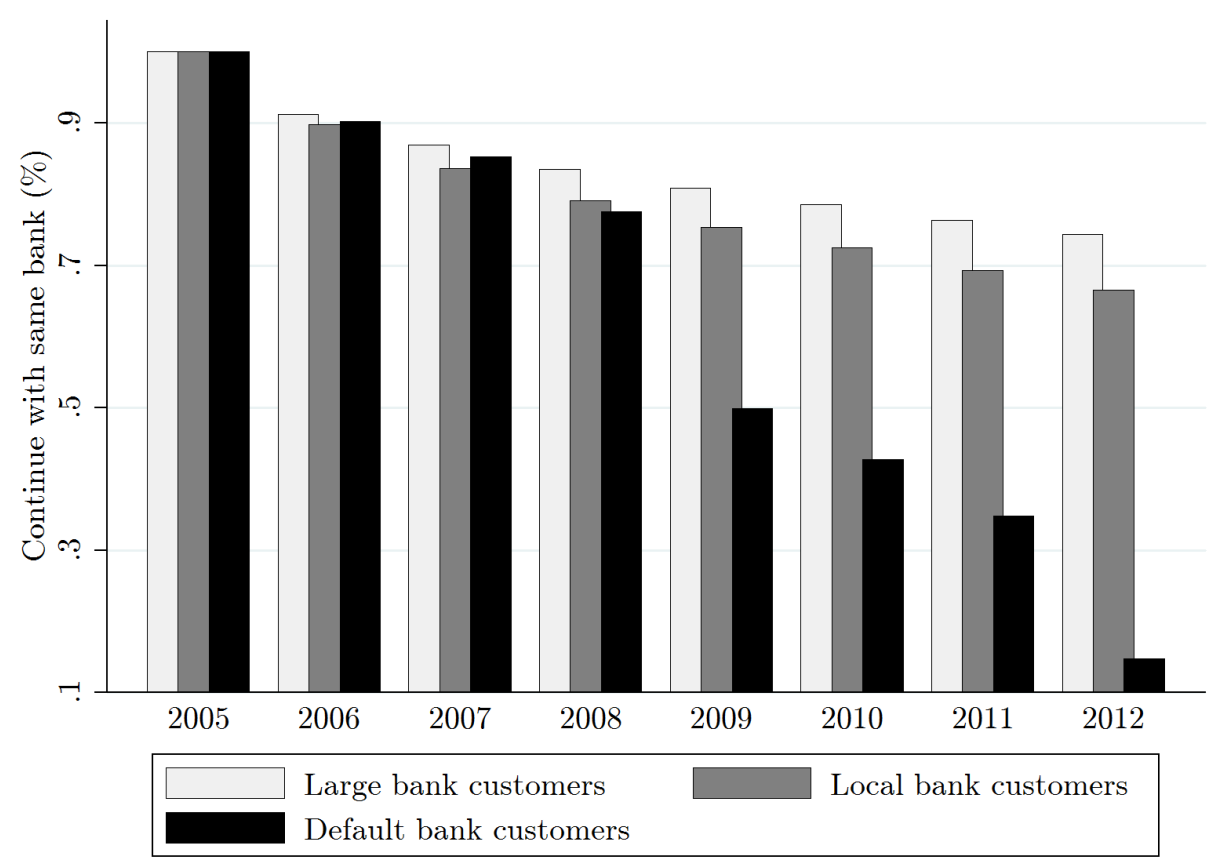


Figure 3: Personal Financing Disruptions and Channels of Financing

The following figure shows an event study plot of the specification in Columns 2 (top-left panel) \& 4 (top-right panel) from Table 6 . The $y$-axis states personal bank loans (left) and the log of liquid wealth (right). The $x$-axis is the year. The black line is the coefficient of the interaction term between Exposed entrepreneurs and year dummies, therefore providing the difference-in-differences estimate. The sample consists of individuals who were entrepreneurs before 2007 and are bank-depositors, while those with investment accounts are excluded. 95\% Confidence intervals are shown.

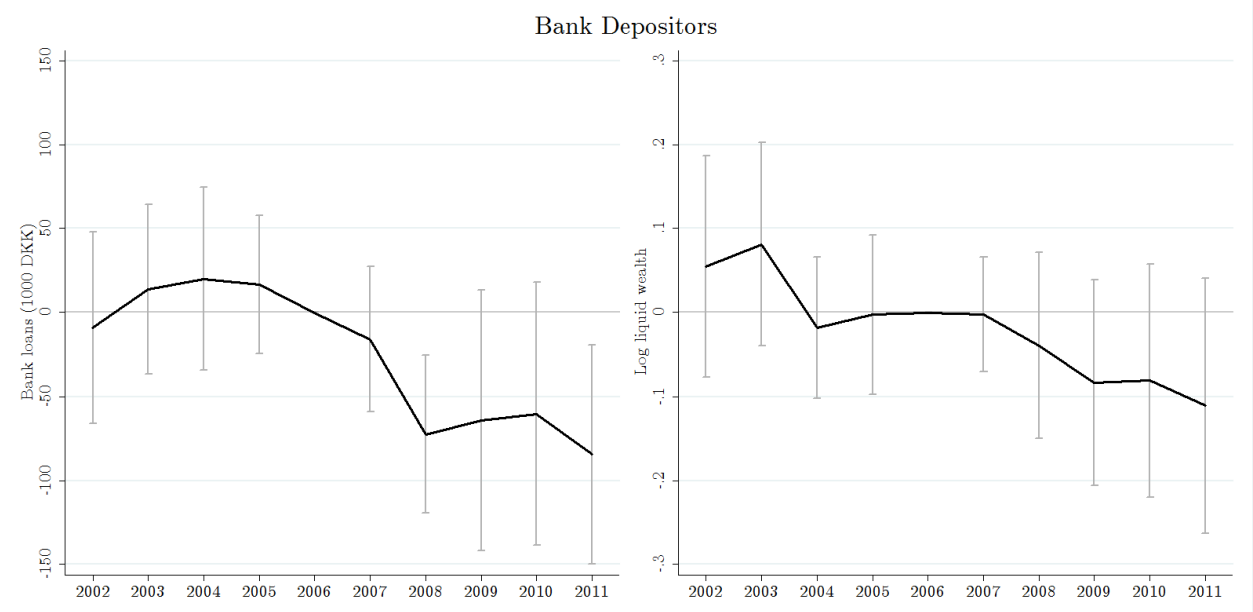

The following figure shows an event study plot of the specification in Columns 6 (bottom-left panel) \& 8 (bottomright panel) from Table 6. The $y$-axis states personal bank loans (left) and the log of liquid wealth (right) . The $x$-axis is the year. The black line is the coefficient of the interaction term between Exposed entrepreneurs and year dummies, therefore providing the difference-in-differences estimate. The sample consists of individuals who were entrepreneurs before 2007 and are bank-investors, while those with deposit accounts in default banks are excluded. 95\% Confidence intervals are shown.

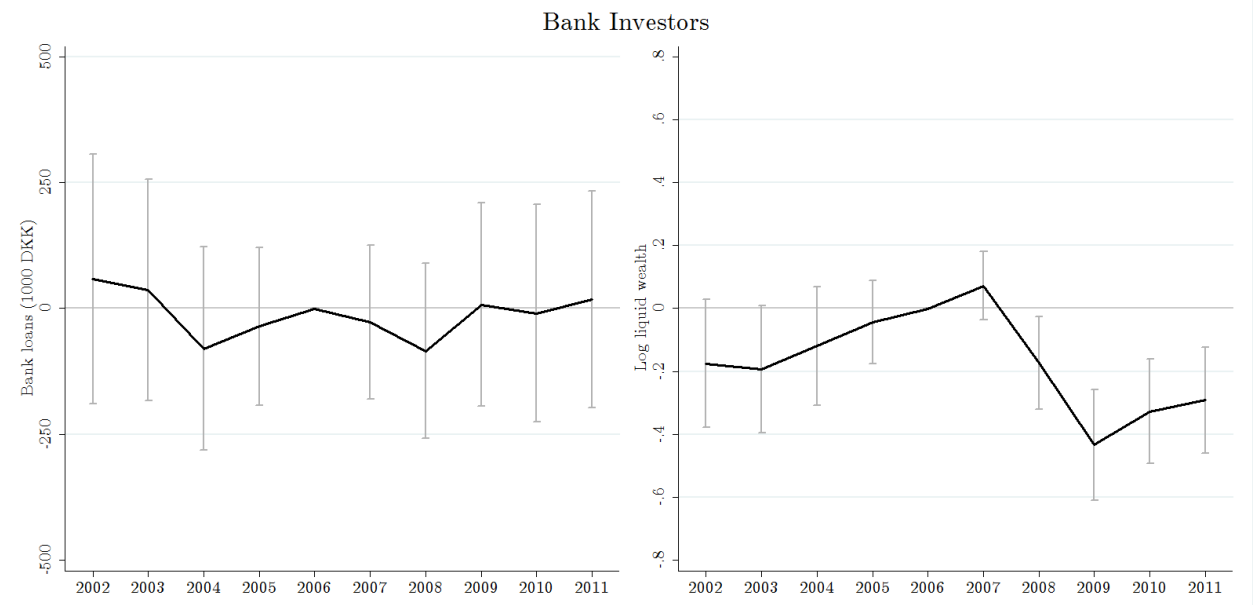




\section{Figure 4: Firm Exit and Size of Wealth Loss}

The following figures plots Equation 5 where the left panel consists of all entrepreneurs and the right panel includes entrepreneurs who began their firm in the years preceding the financial crisis, 2002-2007. The $y$-axis states the probability of exiting from entrepreneurship and the $x$-axis plots the fraction of liquid wealth lost from an investment in a default bank for exposed entrepreneurs after the banking defaults. 95\% confidence intervals are shown.

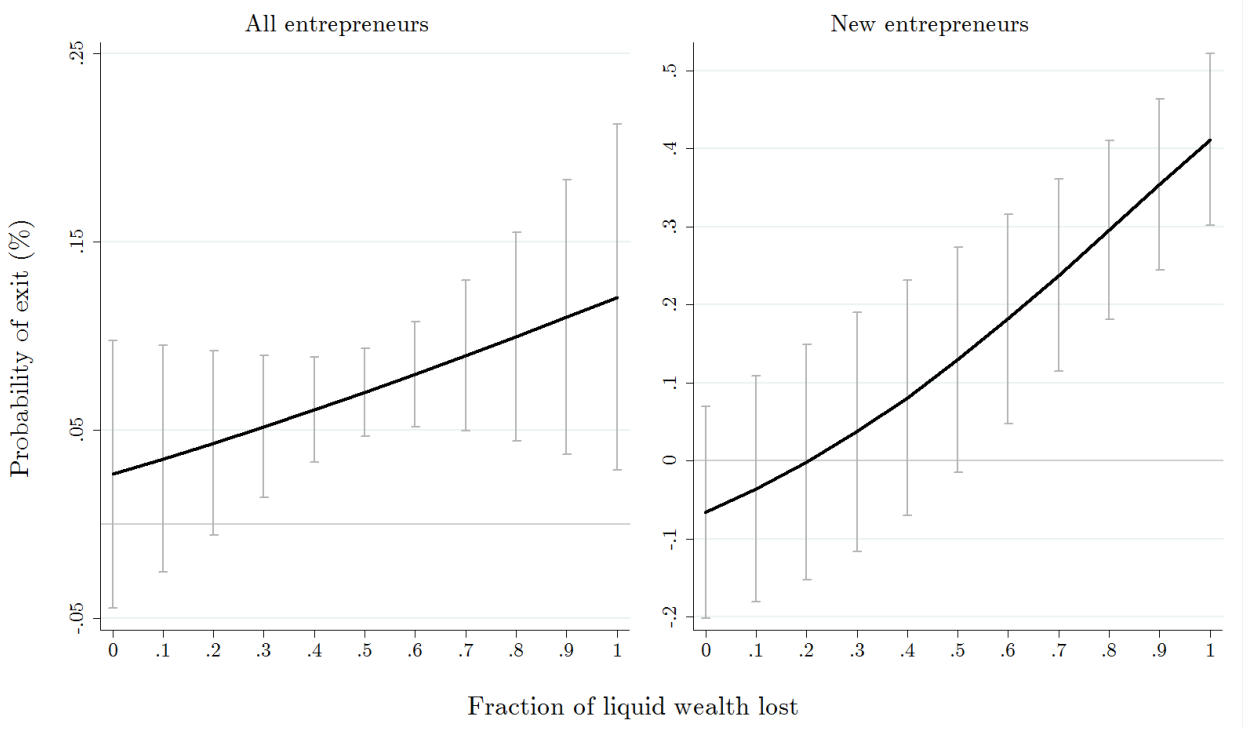

The following figures plots an unreported regression stemming from Table 14. The sample consists of married entrepreneurs who held investments in a retail banking institution prior to the financial crisis. The $y$-axis states the probability of exiting from entrepreneurship and the $x$-axis plots the share of the entrepreneur's income to the total household income for exposed entrepreneurs after the banking defaults. $95 \%$ confidence intervals are shown.

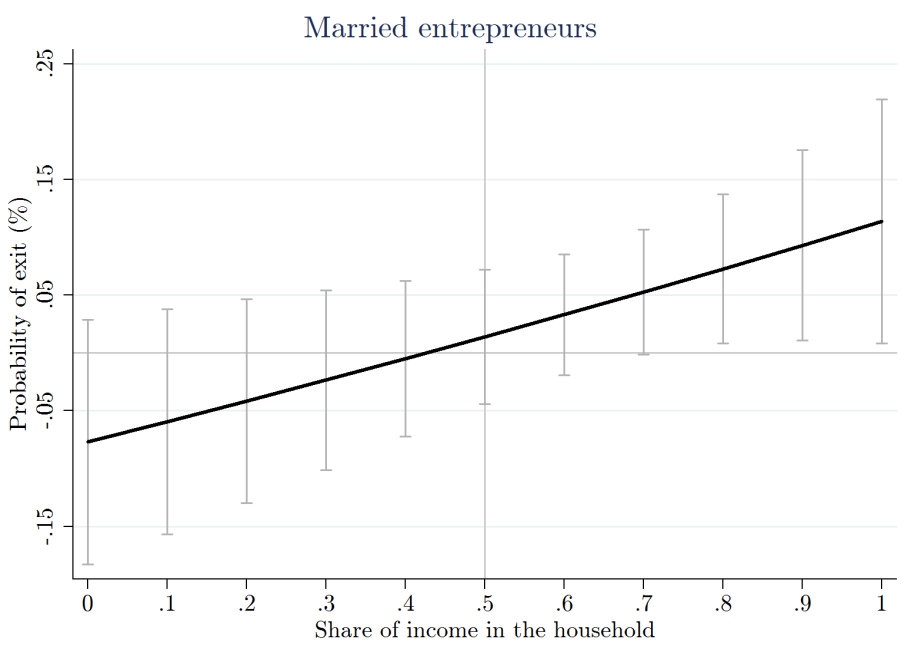


Figure 5: Firm Exit, Access to Debt Financing, and Changes in Personal Wealth - Dynamic Model

The following figure shows an event study plot of the specification in Column 8 from Table 7. The black line is the coefficient of the interaction term between exposed entrepreneurs and year dummies, therefore providing the difference-in-differences estimate. The $y$-axis states the difference in probability of firm exit in a given year between exposed and unexposed entrepreneurs. The $x$-axis is the year. The sample consists of individuals who are entrepreneurs and bank-depositors, while those with investment accounts are excluded. 95\% Confidence intervals are shown.

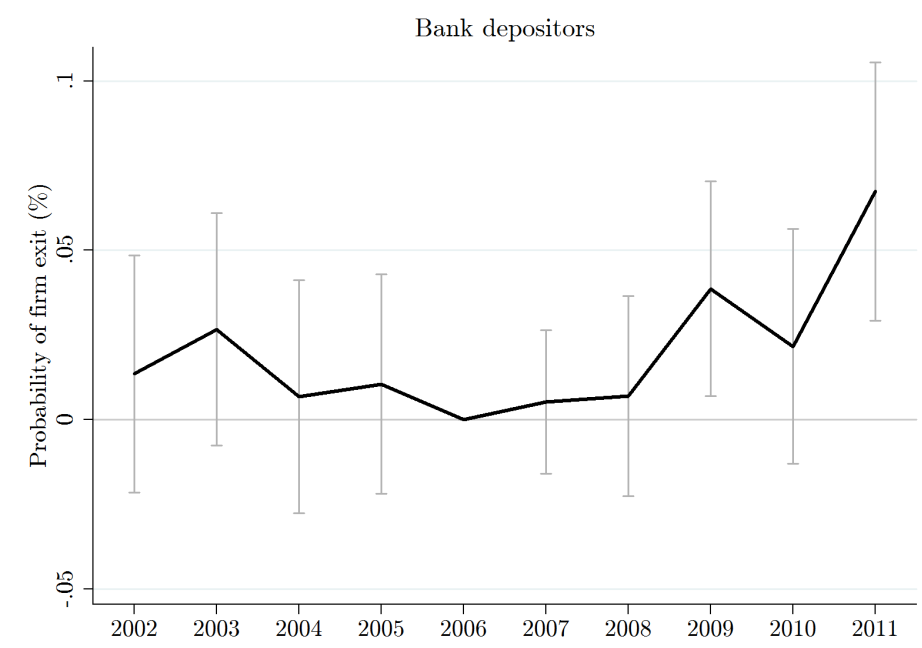

The following figure shows an event study plot of the specification in Column 4 from Table 9. The black line is the coefficient of the interaction term between exposed entrepreneurs and year dummies, therefore providing the difference-in-differences estimate. The $y$-axis states the difference in probability of firm exit in a given year between exposed and unexposed entrepreneurs. The $x$-axis is the year. The sample consists of individuals who are entrepreneurs and bank-investors, while those with deposit accounts in default banks are excluded. $95 \%$ Confidence intervals are shown.

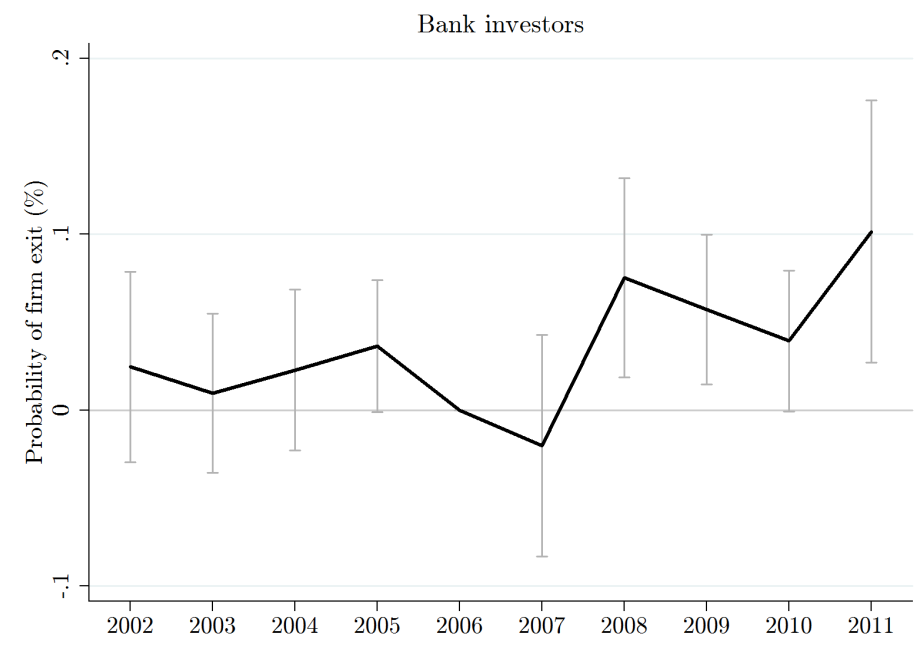


Table A.1: Retail Bank Defaults and Mergers Throughout the Great Recession

The following table outlines the Danish retail banks that faced liquidity challenges after the onset of the 2007-2009 financial crisis. Each of the following troubled banks either defaulted and were taken over by the state-owned Finansiel Stabilitet, or found a private solution (e.g. merger or acquisition). If the bank merged or was acquired the table states the overtaking or surviving retail bank. The municipality and whether the bank was publicly held by investors is also indicated below. Data comes from the author's own research as well as Buchholst and Rangvid (2013).

\begin{tabular}{|c|c|c|c|c|c|}
\hline Year & Troubled bank & Outcome & Publicly held & Municipality & Surviving bank \\
\hline 2008 & BankTrelleborg & Merged & No & Slagelse & Sydbank \\
\hline 2008 & Roskilde & Defaulted & Yes & Roskilde & NA \\
\hline 2008 & Bonusbanken & Merged & No & Herning & Vestjysk Bank \\
\hline 2008 & Sparekassen Spar Mors & Merged & No & Morso & Morso Bank \\
\hline 2008 & EBH Bank & Defaulted & Yes & Jammerbugt & NA \\
\hline 2008 & Localbanken I Nordsaelland & Merged & No & Hillerd & Handelsbanken \\
\hline 2008 & Forstaedernes Bank & Merged & No & Taastrup & Nykredit \\
\hline 2008 & Ringkjobing Bank & Merged & No & Skjern & Vestjysk Bank \\
\hline 2009 & Lokken Sparekasse & Defaulted & No & Hjrring & $\mathrm{NA}$ \\
\hline 2009 & Gudme Raachou & Defaulted & No & Kobenhavn & NA \\
\hline 2009 & Fionia Bank & Defaulted & Yes & Odensee & NA \\
\hline 2010 & Capinordic & Defaulted & Yes & Gentofte & NA \\
\hline 2010 & Finansbank & Merged & No & NA & Sparekassen Lolland \\
\hline 2010 & EIK Banki & Defaulted & No & Farroe Islands & NA \\
\hline 2010 & Skaelsor Bank & Merged & No & Slagelse & Max Bank \\
\hline 2011 & Amagaerbanken & Defaulted & Yes & Kobenhavn S & $\mathrm{NA}$ \\
\hline 2011 & Sparekassen Midtfjord & Merged & No & Vesthimmerland & Sparekassen Himmerland \\
\hline 2011 & Fjordbank Mors & Defaulted & Yes & Morso & NA \\
\hline 2011 & Max Bank & Defaulted & Yes & Naestved & NA \\
\hline 2011 & Sparekassen Limfjorden & Merged & No & Thisted & Sparekassen Vendsyssel \\
\hline 2012 & Sparekassen Farso & Merged & No & Vesthimmerland & Den Jyske Sparekassen \\
\hline 2012 & Sparekassen Ostjylland & Defaulted & No & Favrskov & $\mathrm{NA}$ \\
\hline 2012 & Aarhus Lokalbank & Merged & No & Aarhus & Vestjysk Bank \\
\hline 2012 & Spar Salling Sparekasse & Defaulted & No & Skive & $\mathrm{NA}$ \\
\hline 2012 & Tonder Bank & Defaulted & Yes & Tonder & NA \\
\hline
\end{tabular}


Table A.2: Entrepreneurship and Small Business Owners

Panel A presents the rates of entrepreneurship across the years in the sample. Panel B provides statistics on the number of employees employed by entrepreneurs across the years in the sample. Percentiles are composed of the 5 closest observations due to regulations about data security.

Panel A: Number of entrepreneurs

\begin{tabular}{|c|c|c|c|c|c|c|c|c|c|}
\hline & 2005 & 2006 & 2007 & 2008 & 2009 & 2010 & 2011 & 2012 & Total \\
\hline All individuals & $1,643,542$ & $1,643,542$ & $1,643,542$ & $1,643,542$ & $1,643,542$ & $1,643,542$ & $1,643,542$ & $1,643,542$ & $13,148,336$ \\
\hline Entrepreneurs & 29,398 & 30,082 & 30,177 & 27,265 & 25,628 & 25,191 & 25,095 & 24,730 & 217,566 \\
\hline $\begin{array}{l}\text { Entrepreneur bank } \\
\text { investors }\end{array}$ & 7,553 & 7,449 & 7,302 & 6,480 & 6,134 & 6,084 & 6,027 & 5,911 & 52,940 \\
\hline
\end{tabular}

Panel B: Number of

employees

\begin{tabular}{|c|c|c|c|c|c|c|c|c|c|}
\hline & 2005 & 2006 & 2007 & 2008 & 2009 & 2010 & 2011 & 2012 & Total \\
\hline Mean & 4.8 & 4.8 & 4.9 & 5.6 & 5.4 & 5.4 & 6.2 & 6.4 & 5.4 \\
\hline$p 10$ & 1.0 & 1.0 & 1.0 & 1.0 & 1.0 & 1.0 & 1.0 & 1.0 & 1.0 \\
\hline$p 50$ & 3.0 & 3.0 & 3.0 & 3.0 & 3.0 & 2.0 & 3.0 & 3.0 & 2.9 \\
\hline p90 & 11.0 & 11.0 & 11.0 & 11.0 & 10.0 & 10.0 & 10.0 & 10.0 & 10.5 \\
\hline
\end{tabular}


Table A.3: Investments and Losses from Banking Defaults

The following table provides a tabulation of the distribution of losses for exposed and unexposed bank investors. All investors included held investments in publicly traded retail banks. exposed investors held stocks of retail banks which defaulted, while unexposed investors held stocks which remained solvent. I present the mean, 10th, 50th, and 90th percentiles of total losses, losses as a percentage of savings in 2006, as a percentage of liquid wealth in 2006, and as a percentage of net wealth. Columns 1-4 compare the values of exposed investors to columns 5-8 of unexposed investors. Percentiles are composed of the 5 closest observations due to regulations about data security.

\begin{tabular}{|c|c|c|c|c|c|c|c|c|}
\hline \multirow[b]{2}{*}{ Size of liquidity shock } & \multicolumn{4}{|c|}{ Exposed } & \multicolumn{4}{|c|}{ Unexposed } \\
\hline & Mean & $\mathrm{p} 25$ & $\mathrm{p} 50$ & p75 & Mean & $\mathrm{p} 25$ & $\mathrm{p} 50$ & p75 \\
\hline Losses $(1,000 \mathrm{DKK})$ & -343.85 & -78.68 & -25.76 & -11.45 & -49.73 & -43.91 & -18.16 & -6.44 \\
\hline Percentage of savings (\%) & -30.27 & -50.69 & -12.50 & -3.19 & -20.10 & -22.95 & -6.09 & -1.56 \\
\hline Percentage of liquid wealth (\%) & -21.40 & -30.72 & -9.14 & -2.73 & -13.19 & -15.85 & -4.70 & -1.25 \\
\hline Percentage of net wealth (\%) & -30.92 & -100.00 & -5.26 & -1.01 & -24.40 & -22.87 & -2.35 & -0.49 \\
\hline
\end{tabular}


Table A.4: Firm Entrance and Access to Debt Financing

The following table analyzes the effect of a change in access to bank credit availability on the propensity to enter entrepreneurship stemming from Equation (2). The dependent variable is an indicator variable for entering entrepreneurship, conditional on not being an entrepreneur in the last period. The variable exposure to default bank indicates whether the individual has a primary retail bank which goes on to default during the financial crisis. The variable takes the value of one if year $t$ is after the year of default and zero if otherwise. Panel A represents a specification where all individuals are included in the sample while in Panel B exposed individuals are matched to unexposed individuals who live in the same municipality as the defaulting bank. In both panels Columns 1 \& 2 include all individuals while Columns $3 \& 4$ focus on the bank depositor sample. In all specifications I control for calendar year fixed effects. In Columns $1 \& 3$ the specifications also include default year-cohort controls, and demographic controls including the following: age, age $e^{2}$, male, marriage status, education length in years, log wealth, log income, and child in household, financial education, stock market participation, holding a positive loan balance, receiving unemployment benefits, holding positive housing wealth balance (in either debt or equity), and if the individual is an immigrant. In these specifications, I also control for the year that the firm was established. In Columns $2 \& 4$ the specifications include individual fixed effects and the following time-varying demographic controls: log wealth, log income, and if the entrepreneur has a child or purchases a house at time $t$. Regression coefficients are estimated with OLS. ${ }^{* * *},{ }^{* *}$, and ${ }^{*}$ indicate significant at the 1,5 , and 10 percent levels, respectively. Robust standard errors are clustered at the pre-crisis primary bank level are in parenthesis.

Panel A:

\begin{tabular}{lcccc}
\hline \hline & \multicolumn{2}{c}{ All individuals } \\
Pr(enter) & \multicolumn{2}{c}{ Full sample } & \multicolumn{2}{c}{ Bank depositors } \\
\hline Exposure to default bank & $(1)$ & $(2)$ & $(3)$ & $-0.0009^{* * *}$ \\
& $-0.0010^{* * *}$ & $-0.0009^{* * *}$ & $-0.0010^{* * *}$ & $(0.0002)$ \\
Control variables & $(0.0001)$ & $(0.0002)$ & $(0.0002)$ & Yes \\
Year fixed effects & Yes & Yes & Yes & Yes \\
Individual fixed effects & Yes & Yes & Yes & No \\
$R^{2}$ & No & Yes & 0.0016 & 0.2236 \\
\hline Observations & 0.0016 & 0.2460 & $10,564,249$ & $10,564,249$ \\
\hline \hline
\end{tabular}

Panel B:

\begin{tabular}{lcccc}
\hline \hline & \multicolumn{3}{c}{ Local exposure } \\
& \multicolumn{2}{c}{ Full sample } & \multicolumn{2}{c}{ Bank depositors } \\
Pr(enter) & $(1)$ & $(2)$ & $(3)$ & $(4)$ \\
\hline Exposure to default bank & $-0.0009^{* * *}$ & $-0.0010^{* * *}$ & $-0.0011^{* * *}$ & $-0.0010^{* * *}$ \\
& $(0.0002)$ & $(0.0002)$ & $(0.0002)$ & $(0.0002)$ \\
Control variables & Yes & Yes & Yes & Yes \\
Year fixed effects & Yes & Yes & Yes & Yes \\
Individual fixed effects & No & Yes & No & Yes \\
$R^{2}$ & 0.0017 & 0.2318 & 0.0019 & 0.2099 \\
\hline Observations & $3,922,799$ & $3,922,799$ & $2,528,184$ & $2,528,184$ \\
\hline \hline
\end{tabular}


Figure A.1: Location of Local Banks and Incidence of Bank Defaults in Denmark

This map shows the location of publicly trading retail banks and incidences of bank defaults across municipalities in Denmark from 2006 to 2013 based on bank headquarters. Municipalities with a surviving publicly listed bank are displayed in dark gray. Municipalities in which a troubled bank was involved in a merger or acquisition after the financial crisis are shown in light red. Municipalities in which a publicly traded retail bank defaulted between 2008 and 2012 are displayed in dark red. The two municipalities in which a bank defaulted that was not publicly traded are shown in maroon. Finally, municipalities without a publicly listed retail bank are shown in light gray.

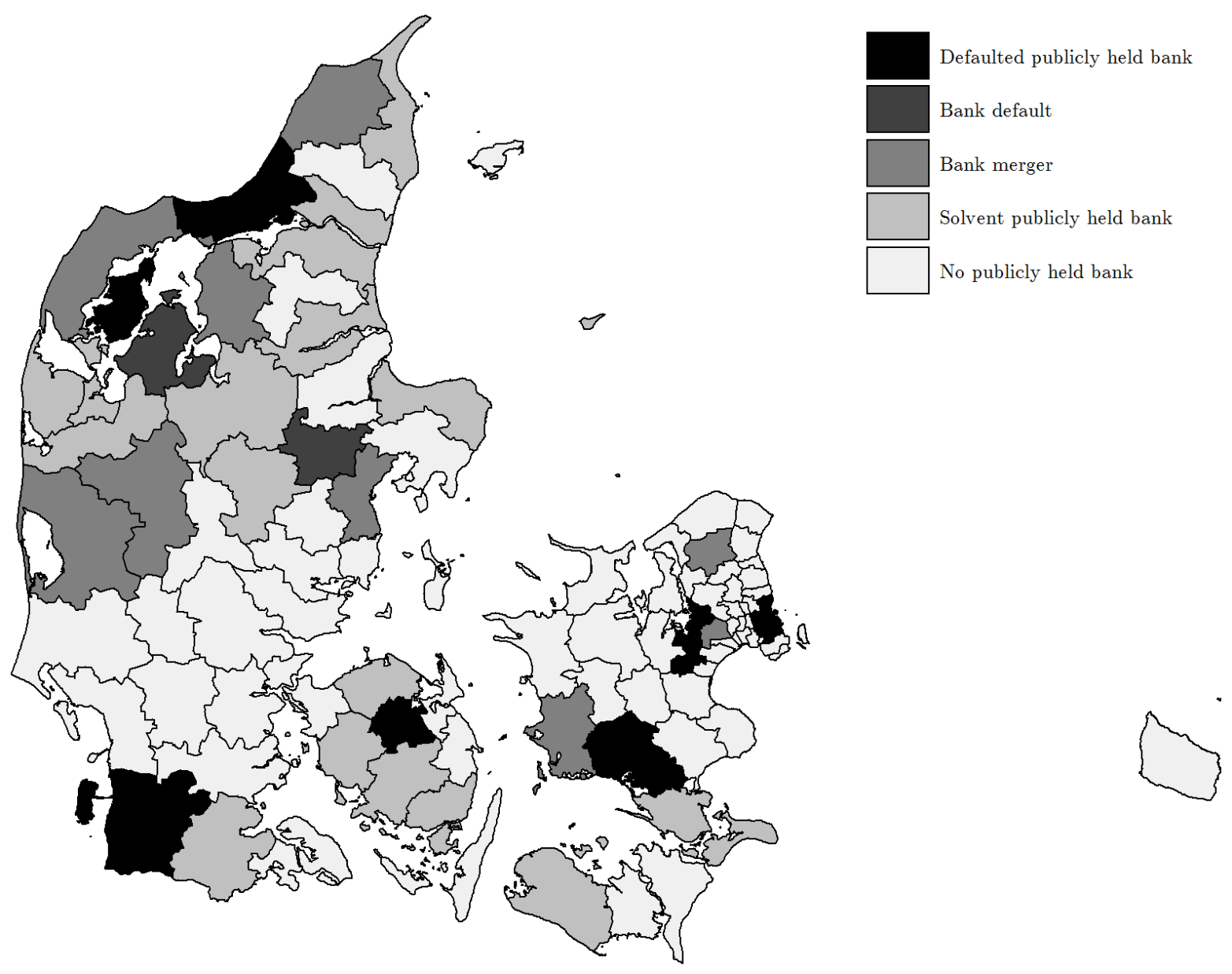




\section{Internet Appendix for "The Effect of Personal Financing Disruptions on Entrepreneurship"}

Tobin Hanspal*

*Research Center SAFE, House of Finance, Goethe University Frankfurt, Theodor-W.-Adorno-Platz 3, 60323 Frankfurt am Main, Germany. E-mail: hanspal@safe.uni-frankfurt.de. 


\section{Table IA.1: Bank Characteristics}

The following table provides bank-level information about deposit customers by different segments of retail banks in Denmark. The columns of Panel A divide all retail banks in the sample by the large, local, and default designation used in Table 5. In Panel B banks are distinguished by the size classification introduced by the National Bank of Denmark and Finansiel Stabilitet. Group 1 (Column 1) includes banks which hold over 50 billion Danish krone in assets (Column 1), Group 2 (Column 2) includes banks which hold between 10 and 50 billion Danish krone in assets, Group 3 (Column 3) includes banks which hold between 250 million and 49 billion Danish krone in assets, and Column 4 includes all Danish banks with assets less than 250 million Danish krone. The rows contain information on the average number of depositors, the share of entrepreneurs and self-employed individuals in each bank. The average deposit balance and average loan balance (all sources of personal bank debt, excluding mortgages) in 1000 DKK of depositors per bank, as well as the market share of depositors captured by the classification type of the bank. In Panel B the number of default banks simply tallies up the number of banks that defaulted by group classification.

Panel A: Bank type

\begin{tabular}{lccc}
\hline & \multicolumn{2}{c}{ Bank type } \\
& Large bank & $\begin{array}{c}\text { Local bank } \\
(2)\end{array}$ & $\begin{array}{c}\text { Default bank } \\
(3)\end{array}$ \\
\hline Average number of depositors & 200,581 & 4,009 & 6,093 \\
Share of entrepreneurs (\%) & 1.85 & 2.36 & 2.58 \\
Share of self-employed (\%) & 3.71 & 4.10 & 4.53 \\
Average deposit balance & 100.21 & 87.55 & 95.81 \\
Average loan balance & 219.46 & 201.60 & 252.89 \\
Market share of depositors (\%) & 61.02 & 26.34 & 4.08 \\
\hline Observations & 5 & 108 & 12 \\
\hline \hline
\end{tabular}

Panel B: FS grouping

\begin{tabular}{lcccc} 
& \multicolumn{3}{c}{ Bank type } \\
& FS Group 1 & FS Group 2 & FS Group 3 & FS Group $>3$ \\
$(1)$ & $(2)$ & $4)$ & 916 \\
\hline Average number of depositors & 238,180 & 24,665 & 4,209 & 1.76 \\
Share of entrepreneurs (\%) & 1.79 & 1.99 & 2.72 & 3.86 \\
Share of self-employed (\%) & 3.81 & 4.01 & 4.27 & 78.23 \\
Average deposit balance & 102.90 & 99.42 & 91.93 & 177.43 \\
Average loan balance & 217.00 & 206.98 & 220.28 & 2.01 \\
Market share of depositors (\%) & 57.97 & 12.01 & 19.46 & 0 \\
Number of default banks & & & 9 & 36 \\
\hline Observations & 0 & 3 & 76 & \\
\hline \hline
\end{tabular}


Table IA.2: Personal Financing Disruptions and Channels of Financing: Dynamic Model

The following table states a dynamic version of the difference-in-differences model in Equations (3) and (4) and Table 6 where exposed ${ }_{i}^{j}$ is interacted with year-dummies in order to test lags and leads of the effect of banking default exposure. In Columns $1 \& 3$ the dependent variable is the total amount of bank loans in 1,000 DKK, while in Columns $2 \& 4$ the dependent variable is the log of the market value, year-end sum of liquid wealth. The coefficients state the difference between exposed and unexposed bank depositors (Columns 1-2) and exposed and unexposed bank investors (Columns 3-4) at varying years across the sample. Year 2006 is omitted. Pre- and post-crisis test are Wald tests for joint significance of pre-crisis periods (2002-2005) and post-crisis periods (20072011), the values displayed in the table state the $p$-values of these tests. All specifications include individualentrepreneur fixed effects and the following time-varying demographic controls: log wealth, log income, and if the entrepreneur has a child or purchases a house at time $t$. Regression coefficients are estimated with OLS. ***, **, and ${ }^{*}$ indicate significant at the 1,5, and 10 percent levels, respectively. Robust standard errors clustered at the pre-crisis primary bank level are in parenthesis.

\begin{tabular}{|c|c|c|c|c|}
\hline & \multicolumn{2}{|c|}{ Bank depositors } & \multicolumn{2}{|c|}{ Bank investors } \\
\hline & $\begin{array}{l}\text { Bank loans } \\
\text { (1) }\end{array}$ & $\begin{array}{c}\text { Liquid wealth } \\
\text { (2) }\end{array}$ & $\begin{array}{c}\text { Bank loans } \\
(3)\end{array}$ & $\begin{array}{c}\text { Liquid wealth } \\
\text { (4) }\end{array}$ \\
\hline $2002 \times$ exposed $_{i}^{j}$ & $\begin{array}{l}-24.7021 \\
(31.0940)\end{array}$ & $\begin{array}{c}0.0300 \\
(0.0766)\end{array}$ & $\begin{array}{c}58.4429 \\
(150.2760)\end{array}$ & $\begin{array}{l}-0.1751 \\
(0.1232)\end{array}$ \\
\hline $2003 \times \operatorname{exposed}_{i}^{j}$ & $\begin{array}{l}-4.5936 \\
(29.1435)\end{array}$ & $\begin{array}{c}0.0851 \\
(0.0741)\end{array}$ & $\begin{array}{c}36.1650 \\
(133.5564)\end{array}$ & $\begin{array}{l}-0.1929 \\
(0.1227)\end{array}$ \\
\hline $2004 \times \operatorname{exposed}_{i}^{j}$ & $\begin{array}{l}16.2110 \\
(26.8254)\end{array}$ & $\begin{array}{l}-0.0415 \\
(0.0693)\end{array}$ & $\begin{array}{c}-79.4794 \\
(122.7937)\end{array}$ & $\begin{array}{l}-0.1195 \\
(0.1149)\end{array}$ \\
\hline $2005 \times \operatorname{exposed}_{i}^{j}$ & $\begin{array}{c}6.0448 \\
(23.4175)\end{array}$ & $\begin{array}{c}0.0166 \\
(0.0641)\end{array}$ & $\begin{array}{l}-35.3909 \\
(95.1308)\end{array}$ & $\begin{array}{l}-0.0434 \\
(0.0801)\end{array}$ \\
\hline $2007 \times \operatorname{exposed}_{i}^{j}$ & $\begin{array}{l}-21.1532 \\
(24.1552)\end{array}$ & $\begin{array}{c}0.0002 \\
(0.0621)\end{array}$ & $\begin{array}{l}-27.3123 \\
(92.8866)\end{array}$ & $\begin{array}{c}0.0723 \\
(0.0661)\end{array}$ \\
\hline $2008 \times \operatorname{exposed}_{i}^{j}$ & $\begin{array}{l}-49.1930^{*} \\
(29.6366)\end{array}$ & $\begin{array}{l}-0.0365 \\
(0.0702)\end{array}$ & $\begin{array}{c}-84.2947 \\
(105.8445)\end{array}$ & $\begin{array}{l}-0.1726^{*} \\
(0.0895)\end{array}$ \\
\hline $2009 \times \operatorname{exposed}_{i}^{j}$ & $\begin{array}{l}-67.5873^{* *} \\
(29.8271)\end{array}$ & $\begin{array}{l}-0.0408 \\
(0.0711)\end{array}$ & $\begin{array}{c}7.2738 \\
(122.5285)\end{array}$ & $\begin{array}{l}-0.4332^{* * *} \\
(0.1068)\end{array}$ \\
\hline $2010 \times \operatorname{exposed}_{i}^{j}$ & $\begin{array}{l}-55.6564^{*} \\
(33.2805)\end{array}$ & $\begin{array}{l}-0.0253 \\
(0.0713)\end{array}$ & $\begin{array}{c}-9.5658 \\
(131.1709)\end{array}$ & $\begin{array}{l}-0.3267^{* * *} \\
(0.1013)\end{array}$ \\
\hline $2011 \times$ exposed $_{i}^{j}$ & $\begin{array}{l}-68.7237^{* *} \\
(33.7224)\end{array}$ & $\begin{array}{l}-0.0618 \\
(0.0730)\end{array}$ & $\begin{array}{c}18.0143 \\
(130.9474)\end{array}$ & $\begin{array}{l}-0.2914^{* * *} \\
(0.1019)\end{array}$ \\
\hline Pre-crisis test $p$-value & 0.4454 & 0.3178 & 0.1955 & 0.5880 \\
\hline Post-crisis test $p$-value & 0.2489 & 0.9461 & 0.7420 & 0.0002 \\
\hline Control variables & Yes & Yes & Yes & Yes \\
\hline Individual fixed effects & Yes & Yes & Yes & Yes \\
\hline$R^{2}$ & 0.6975 & 0.4304 & 0.6979 & 0.5749 \\
\hline Observations & 250,400 & 250,400 & 97,950 & 97,950 \\
\hline
\end{tabular}


Table IA.3: Firm Exit, Employment Decisions, and Personal Financing Disruptions: Dynamic Model

The following table states a dynamic version of the difference-in-differences model in Equation (2) and Tables 9 \& 13 where exposed ${ }_{i}^{j}$ is interacted with year-dummies in order to test lags and leads of the effect of banking default exposure. In Columns $1 \& 2$ the dependent variable the probability of exiting entrepreneurship in year conditional on being an entrepreneur in the last period, while in Columns $3 \& 4$ the dependent variable is the number of employees employed by the entrepreneur in year $t$. The coefficients state the difference between exposed and unexposed bank depositors (Columns $1 \& 3$ ) and exposed and unexposed bank investors (Columns 2 \& 4) at varying years across the sample. Year 2006 is omitted. Pre- and post-crisis test are Wald tests for joint significance of pre-crisis periods (2002-2005) and post-crisis periods (2007-2011), the values displayed in the table state the $p$-values of these tests. All specifications include individual-entrepreneur fixed effects and the following timevarying demographic controls: log wealth, log income, and if the entrepreneur has a child or purchases a house at time $t$. Regression coefficients are estimated with OLS. ${ }^{* * *},{ }^{* *}$, and ${ }^{*}$ indicate significant at the 1,5 , and 10 percent levels, respectively. Robust standard errors clustered at the pre-crisis primary bank level are in parenthesis.

\begin{tabular}{|c|c|c|c|c|}
\hline & \multicolumn{2}{|c|}{$\operatorname{Pr}($ exit) } & \multicolumn{2}{|c|}{ Number of employees } \\
\hline & $\begin{array}{l}\text { Depositors } \\
(1)\end{array}$ & $\begin{array}{c}\text { Investors } \\
(2)\end{array}$ & $\begin{array}{c}\text { Depositors } \\
(3)\end{array}$ & $\begin{array}{c}\text { Investors } \\
(4)\end{array}$ \\
\hline $2002 \times$ exposed $_{i}^{j}$ & $\begin{array}{c}0.0077 \\
(0.0210)\end{array}$ & $\begin{array}{c}0.0244 \\
(0.0238)\end{array}$ & $\begin{array}{l}-0.4023^{*} \\
(0.2138)\end{array}$ & $\begin{array}{l}-0.4648 \\
(0.2798)\end{array}$ \\
\hline $2003 \times \operatorname{exposed}_{i}^{j}$ & $\begin{array}{c}0.0335 \\
(0.0208)\end{array}$ & $\begin{array}{c}0.0093 \\
(0.0219)\end{array}$ & $\begin{array}{l}-0.1311 \\
(0.1483)\end{array}$ & $\begin{array}{l}-0.5092^{* *} \\
(0.2393)\end{array}$ \\
\hline $2004 \times \operatorname{exposed}_{i}^{j}$ & $\begin{array}{c}0.0041 \\
(0.0210)\end{array}$ & $\begin{array}{c}0.0220 \\
(0.0233)\end{array}$ & $\begin{array}{l}-0.1633 \\
(0.1394)\end{array}$ & $\begin{array}{l}-0.2893 \\
(0.2346)\end{array}$ \\
\hline $2005 \times \operatorname{exposed}_{i}^{j}$ & $\begin{array}{c}0.0028 \\
(0.0195)\end{array}$ & $\begin{array}{c}0.0366 \\
(0.0231)\end{array}$ & $\begin{array}{l}-0.1068 \\
(0.1283)\end{array}$ & $\begin{array}{l}-0.1699 \\
(0.1717)\end{array}$ \\
\hline $2007 \times$ exposed $_{i}^{j}$ & $\begin{array}{l}-0.0036 \\
(0.0207)\end{array}$ & $\begin{array}{l}-0.0208 \\
(0.0255)\end{array}$ & $\begin{array}{l}-0.0193 \\
(0.1135)\end{array}$ & $\begin{array}{l}-0.1839 \\
(0.1811)\end{array}$ \\
\hline $2008 \times$ exposed $_{i}^{j}$ & $\begin{array}{l}-0.0019 \\
(0.0207)\end{array}$ & $\begin{array}{l}0.0756^{* * *} \\
(0.0282)\end{array}$ & $\begin{array}{l}-0.2424 \\
(0.1488)\end{array}$ & $\begin{array}{l}-0.1511 \\
(0.2287)\end{array}$ \\
\hline $2009 \times$ exposed $_{i}^{j}$ & $\begin{array}{c}0.0299 \\
(0.0218)\end{array}$ & $\begin{array}{c}0.0571^{* *} \\
(0.0269)\end{array}$ & $\begin{array}{l}-0.2079 \\
(0.1553)\end{array}$ & $\begin{array}{l}-0.4211^{*} \\
(0.2430)\end{array}$ \\
\hline $2010 \times$ exposed $_{i}^{j}$ & $\begin{array}{c}0.0060 \\
(0.0215)\end{array}$ & $\begin{array}{c}0.0392 \\
(0.0261)\end{array}$ & $\begin{array}{l}-0.2773 \\
(0.2085)\end{array}$ & $\begin{array}{l}-0.5622^{* *} \\
(0.2361)\end{array}$ \\
\hline $2011 \times \operatorname{exposed}_{i}^{j}$ & $\begin{array}{c}0.0399^{*} \\
(0.0229)\end{array}$ & $\begin{array}{l}0.1018^{* * *} \\
(0.0297)\end{array}$ & $\begin{array}{l}-0.3616^{* *} \\
(0.1692)\end{array}$ & $\begin{array}{l}-0.7060^{* * *} \\
(0.1554)\end{array}$ \\
\hline $2012 \times$ exposed $_{i}^{j}$ & & & $\begin{array}{l}-0.1694 \\
(0.2075)\end{array}$ & $\begin{array}{l}-0.6674^{* * *} \\
(0.2330)\end{array}$ \\
\hline Pre-crisis test $p$-value & 0.4666 & 0.5276 & 0.4399 & 0.2911 \\
\hline Post-crisis test $p$-value & 0.2808 & 0.0003 & 0.0245 & 0.0002 \\
\hline Control variables & Yes & Yes & Yes & Yes \\
\hline Individual fixed effects & Yes & Yes & Yes & Yes \\
\hline$R^{2}$ & 0.2955 & 0.2806 & 0.7468 & 0.7994 \\
\hline Observations & 145,371 & 69,114 & 150,347 & 70,779 \\
\hline
\end{tabular}




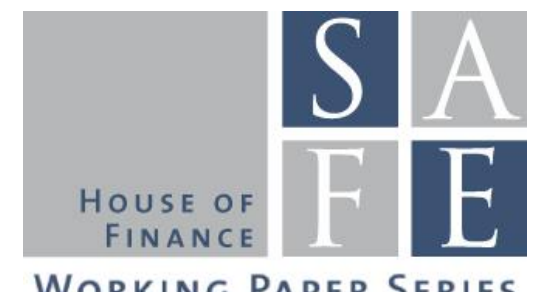

Working PAPER SERIES

\section{Recent Issues}

No. 160 Domenico Rocco Cambrea, Stefano Colonnello, Giuliano Curatola, Giulia Fantini

No. 159 Monica Billio, Michael Donadelli, Antonio Paradiso, Max Riedel

No. 158 Michael Donadelli, Renatas Kizys, Max Riedel

No. 157 Steffen Meyer, Linda Urban, Sophie Ahlswede

No. 156 Reint Gropp, Thomas Mosk, Steven Ongena, Carlo Wix

No. 155 Vahid Saadi

No. 154 Brigitte Haar

No. 153 Julia Hirsch, Uwe Walz

No. 152 Viral Acharya, Tim Eisert, Christian Eufinger, Christian Hirsch

No. 151 Michael Schneider, Fabrizio Lillo, Loriana Pelizzon

No. 150 Vanya Horneff, Raimond Maurer, Olivia S. Mitchell

No. 149 Massimiliano Caporin, Aleksey Kolokolov, Roberto Renò

No. 148 Sven-Thorsten Jakusch
Abandon Ship: Inside Debt and Risk-Taking Incentives in Bad Times

Which Market Integration Measure?

Globally Dangerous Diseases: Bad News for Main Street, Good News for Wall Street?

Does feedback on personal investment success help?

Bank Response To Higher Capital Requirements: Evidence From A QuasiNatural Experiment

Mortgage Supply and the US Housing Boom: The Role of the Community Reinvestment Act

Shareholder Wealth vs. Stakeholder interests? Evidence from Code Compliance under the German Corporate Governance Code

The Financing Dynamics of Newly Founded Firms

Whatever it Takes: The Real Effects of Unconventional Monetary Policy

How Has Sovereign Bond Markets Liquidity Changed? - An Illiquidity Spillover Analysis

Putting the Pension back in $401(\mathrm{k})$ Plans: Optimal versus Default Longevity Income Annuities

Systemic Co-Jumps

On the Applicability of Maximum Likelihood Methods: From Experimental to Financial Data 